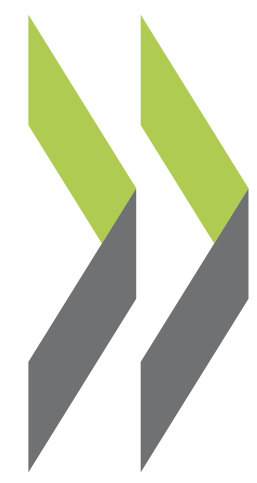

OECD Economics Department Working Papers No. 1624

The Future of Housing: Policy Scenarios

Boris Cournède, Volker Ziemann, Frederica De Pace 


\section{ECONOMICS DEPARTMENT}

\section{THE FUTURE OF HOUSING: POLICY SCENARIOS}

\section{ECONOMICS DEPARTMENT WORKING PAPERS No. 1624}

By Boris Cournède, Federica De Pace and Volker Ziemann

OECD Working Papers should not be reported as representing the official views of the OECD or its member countries. The opinions expressed and arguments employed are those of the author(s).

Authorised for publication by Luiz de Mello, Director, Policy Studies Branch, Economics Department.

All Economics Department Working Papers are available at www.oecd.org/eco/workingpapers.

JT03466165 
OECD Working Papers should not be reported as representing the official views of the OECD or of its member countries. The opinions expressed and arguments employed are those of the author(s).

Working Papers describe preliminary results or research in progress by the author(s) and are published to stimulate discussion on a broad range of issues on which the OECD works.

Comments on Working Papers are welcomed, and may be sent to OECD Economics Department, 2 rue André Pascal, 75775 Paris Cedex 16, France, or by e-mail to eco.contact@oecd.org.

All Economics Department Working Papers are available at www.oecd.org/eco/workingpapers

This document and any map included herein are without prejudice to the status of or sovereignty over any territory, to the delimitation of international frontiers and boundaries and to the name of any territory, city or area.

The statistical data for Israel are supplied by and under the responsibility of the relevant Israeli authorities. The use of such data by the OECD is without prejudice to the status of the Golan Heights, East Jerusalem and Israeli settlements in the West Bank under the terms of international law.

\section{(C) OECD (2020)}

You can copy, download or print OECD content for your own use, and you can include excerpts from OECD publications, databases and multimedia products in your own documents, presentations, blogs, websites and teaching materials, provided that suitable acknowledgment of OECD as source and copyright owner is given. requests for commercial use and translation rights should be submitted to rights@oecd.org 


\section{Abstract / Résumé}

\section{The Future of Housing: Policy Scenarios}

By combining fresh estimates of housing supply and prices with recent long-term projections for their fundamental drivers such as population, income and interest rates, this paper produces scenarios for residential investment and real house prices up to 2050. For half of the covered countries, projected increases in house prices are large enough to outpace real incomes, thereby further eroding housing affordability. The paper illustrates and quantifies how housing policies can make a difference. Removing mortgage interest relief eases price pressures and can contribute to more affordable housing. Likewise, streamlining land-use governance and easing rental control can help unlock housing supply, make housing markets more efficient and, ultimately, housing more affordable.

JEL classification codes: H7, R14, R21, R31, R52

Keywords: Housing affordability, housing supply, rent control, land-use policy, mortgage interest relief

\section{L'avenir du logement : scénarios de politiques publiques}

En combinant de nouvelles estimations de l'offre et des prix des logements avec de récentes projections de long terme pour les facteurs fondamentaux tels que la population, les revenus et les taux d'intérêt, ce document produit des scénarios pour l'investissement résidentiel et les prix réels des logements jusqu'en 2050. Pour la moitié des pays couverts, les augmentations prévues des prix des logements sont suffisamment importantes pour dépasser les revenus réels, rendant l'accès au logement plus difficile. L'étude illustre et quantifie comment les politiques de logement peuvent faire une différence. La suppression des allégements fiscaux relatifs aux intérêts hypothécaires atténue la pression sur les prix et rend les logements plus abordables. De même, la rationalisation de la gouvernance de la réglementation foncière et l'assouplissement de l'encadrement des loyers peuvent aider à débloquer l'offre de logements, fluidifier les marchés du logement plus efficaces et, en fin de compte, rendre les logements plus abordables.

Classification JEL : H7, R14, R21, R31, R52

Mots-clés : Abordabilité du logement, offre de logements, contrôle des loyers, politique d'aménagement du territoire, allégements fiscaux relatifs aux intérêts hypothécaires 


\section{Table of Contents}

The Future of Housing: Policy Scenarios 5

1. Introduction and main findings 5

2. A framework for long-term projections of house prices and investment 8

3. Future trends in housing affordability: Baseline and policy scenarios 13

4. Digital home sharing platforms $\quad 20$

References 24

Annex A: Housing, urban mobility and the environment - A tale of multidimensionality

1. Greening urban mobility 31

2. Decarbonising housing $\quad 37$

\section{Tables}

$\begin{array}{lr}\text { Table 1. Price equation } & 11\end{array}$

Table 2. Investment equation $\quad 12$

Table A.1. Urban mobility performance influences house prices $\quad 35$

\section{Figures}

Figure 1. House price-to-income ratios $\quad 6$

Figure 2. Secular trends in real house prices and construction costs $\quad 7$

Figure 3. A stock-flow framework for housing 9

Figure 4. Selected housing policy indicators $r$

Figure 5. Baseline changes in the housing stock, house prices and price-to-income ratios 14

Figure 6. Housing and inequality $\quad 15$

Figure 7. Past and projected developments of housing demand drivers $\quad 16$

Figure 8. House price sensitivity with respect to changes of fundamental demand drivers 17

Figure 9. Simulated impact of reform scenarios on price-to-income ratios by $2050 \quad 19$

Figure 10. Occupants of flats listed on Airbnb for three months or longer relative to city population 21

Figure 11. Occupants of flats listed on Airbnb relative to city population 23

Figure A.1. The future of housing can be sustainable, inclusive and efficient $\quad 31$

Figure A.2. Urban mobility is projected to expand over 2015-50 33

Figure A.3. Urban mobility performance by car varies considerably across OECD countries 34

Figure A.4. Reducing congestion could boost housing affordability $\quad 35$

Figure A.5. Urban passenger transport $\mathrm{CO}_{2}$ emissions are projected to abate over 2015-50 36

Figure A.6. Housing accounts for $22 \%$ of final energy use and $17 \%$ of energy-related $\mathrm{CO}_{2}$ emissions 37

Figure A.7. The IEA ETP model projects energy demand and emissions 38

Figure A.8. High ambition is required to bring housing-related emissions down 39

Figure A.9. Tightening building standards and accelerating renovation are projected to increase prices 40

\section{Boxes}

Box 1. House prices in the very long run 6

Box 2. The rise of home-sharing digital platforms: The case of Airbnb 22

Box A.1. The IEA Energy Technology Perspectives Model 38 


\title{
The Future of Housing: Policy Scenarios
}

\author{
By Boris Cournède, Federica De Pace and Volker Ziemann ${ }^{1}$
}

\section{Introduction and main findings}

Decent and affordable housing, a key concern for households, has come even more to the forefront in recent decades because of the strong surge in housing costs. They have made good-quality housing increasingly difficult to afford for many. Real house prices have risen considerably in many countries over the past 30 years, in a marked acceleration of a secular trend that started in the middle of the $20^{\text {th }}$ century. In supply-constrained cities with good amenities, construction could not keep up with strongly rising demand. As a result, prices rose sharply. Even at the national level, house prices have risen much faster than household income in many countries (Figure 1). History, however, suggests that real house prices need not always trend up, as the period of strong population growth and very rapid urbanisation of the first half of the $20^{\text {th }}$ century was characterised by the absence of such an upward trend (Box 1).

Will the strong upward trend of house prices continue and if this were so, what policy reforms could make housing affordable again? This paper sheds light on these issues by developing a simulation framework to provide a baseline and policy scenarios for residential investment, the housing stock and house prices until 2050. The simulation framework builds on recent analyses undertaken for the Working Party, which investigated the fundamental and policy drivers of housing supply and prices at the national and regional level (Cavalleri, Cournède and Özsögüt, 2019 [1]; Bétin and Ziemann, 2019 $9_{[2]}$ ). It extends the findings from this analysis in a way that is suitable for long-term projections and combines the results with the latest update of the OECD Economic Outlook long-term baseline scenario for key economic aggregates. This combination allows mapping out the long-term consequences of the fundamental drivers of housing markets on house prices and investment and, crucially, gauging the effects of policy reform pathways on affordability. The scenarios measure overall affordability by the ratio of the price of a $100 \mathrm{~m}^{2}$ dwelling to average household disposable income; the paper also discusses some implications of the projected house price paths for different points of the income distribution.

Achieving the climate change targets of the Paris Agreement via decarbonisation and the transformation of urban mobility due to transport mode sharing provides challenges and opportunities for the housing

\footnotetext{
1 The authors are members of the OECD Economics Department and can be contacted at these e-mail addresses: boris.cournede@oecd.org, federica.depace@oecd.org and volker.ziemann@oecd.org. They are indebted to Peter Hoeller for his oversight of the project and contributions to the Annex. They are grateful to Michael Abendschein, Christophe André, Andrew Barker, Hansjörg Blöchliger, Laurence Boone, Orsetta Causa, Maria Chiara Cavalleri, Alain de Serres, Luiz de Mello, Yvan Guillemmette, Mikkel Hermansen, Priscilla Fialho, Åsa Johansson (OECD Economics Department), Willem Adema, Jonas Fluchtmann and Marissa Plouin (OECD Directorate for Employment, Labour and Social Affairs) as well as Delegates of the OECD Working Party No. 1 on Macroeconomic and Structural Policy Analysis of the OECD Economic Policy Committee for their comments. Special thanks go to Celia Rutkoski for editorial support.
} 
sector. Long-term decarbonisation scenarios by the International Energy Agency and urban transport scenarios by the International Transport Forum provide insights about these future drivers of housing transformation (see Annex). This transformation will also have consequences for house prices and housing supply, the scale of which can be gauged using the simulation framework and stylised assumptions.

This study focuses on long-term aggregate trends for housing volume and prices to 2050 . As such, it looks beyond the near and medium-term impacts of the COVID-19 on supply and prices. By looking at the aggregate housing stock, it also abstracts from the possible changes in the composition of housing that may result from the COVID-19 crisis, such as a possible shift towards more dwellings with gardens. A separate OECD analysis has addressed these issues (OECD, 2020[3]).

\section{Figure 1. House price-to-income ratios}

Years of average household disposable income required to purchase an average $100 \mathrm{~m}^{2} \mathrm{dwelling}$

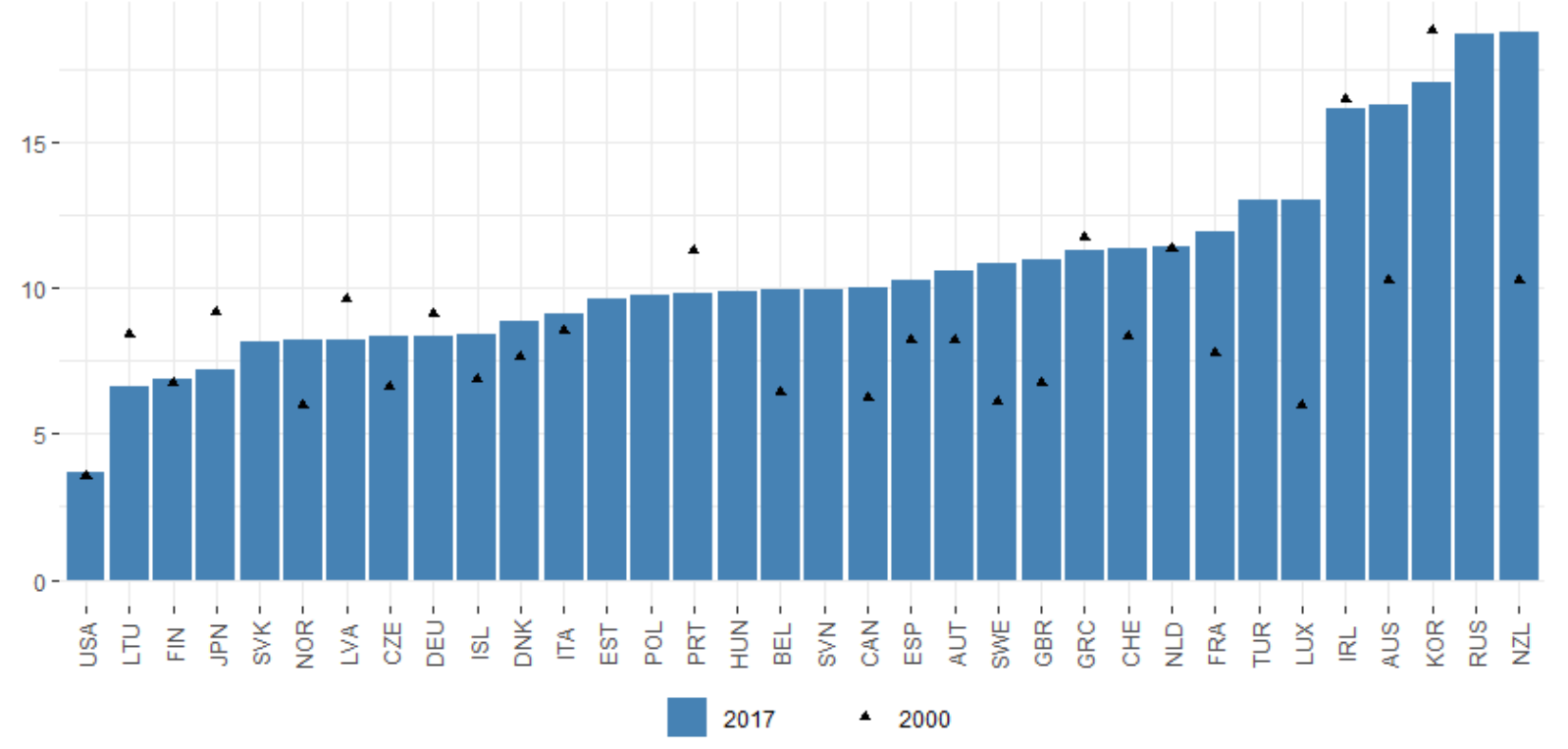

Note: For Australia, Canada, New Zealand and Korea numbers correspond to 2016 instead of 2017.

Source: Bricongne, Turrini and Pontuch (2019 $[4])$.

\section{Box 1. House prices in the very long run}

The strong trend increase in real house prices over the past three decades stands in stark contrast with earlier historical developments. The second half of the $19^{\text {th }}$ century started in many European countries with real house price increases, which triggered intense discussions about how rising rents impoverished workers (Engels, 1872/73[5]). The turn and first half of the $20^{\text {th }}$ century were characterised by real house prices moving roughly in step or even less so than real construction costs (Figure 2). This stability is remarkable in at least two ways. First, it occurred despite the scarcity of manpower and capital that wartime losses and destruction entailed in many countries. Second, real house prices remained stable or showed only limited increases despite the huge improvements in housing quality that occurred in this 
period, as many homes became connected to water, sewage and electricity networks. The available price indices for this period only imperfectly adjust for quality.

The even larger scale of losses in human lives and capital from World War II presumably plays a role alongside the baby boom in explaining the rise in real house prices observed in the aftermath of the war. This steady rise was followed in most countries by a sharp acceleration since the mid-1980s: real house prices have more than doubled in this period on average across the countries shown in Figure 2. Notable exceptions are Japan and, until very recently, Germany. This rise cannot be explained by real construction costs, which, outside the United Kingdom, have been mostly flat or evolved in ways that appear largely disconnected from real house prices.

Figure 2. Secular trends in real house prices and construction costs
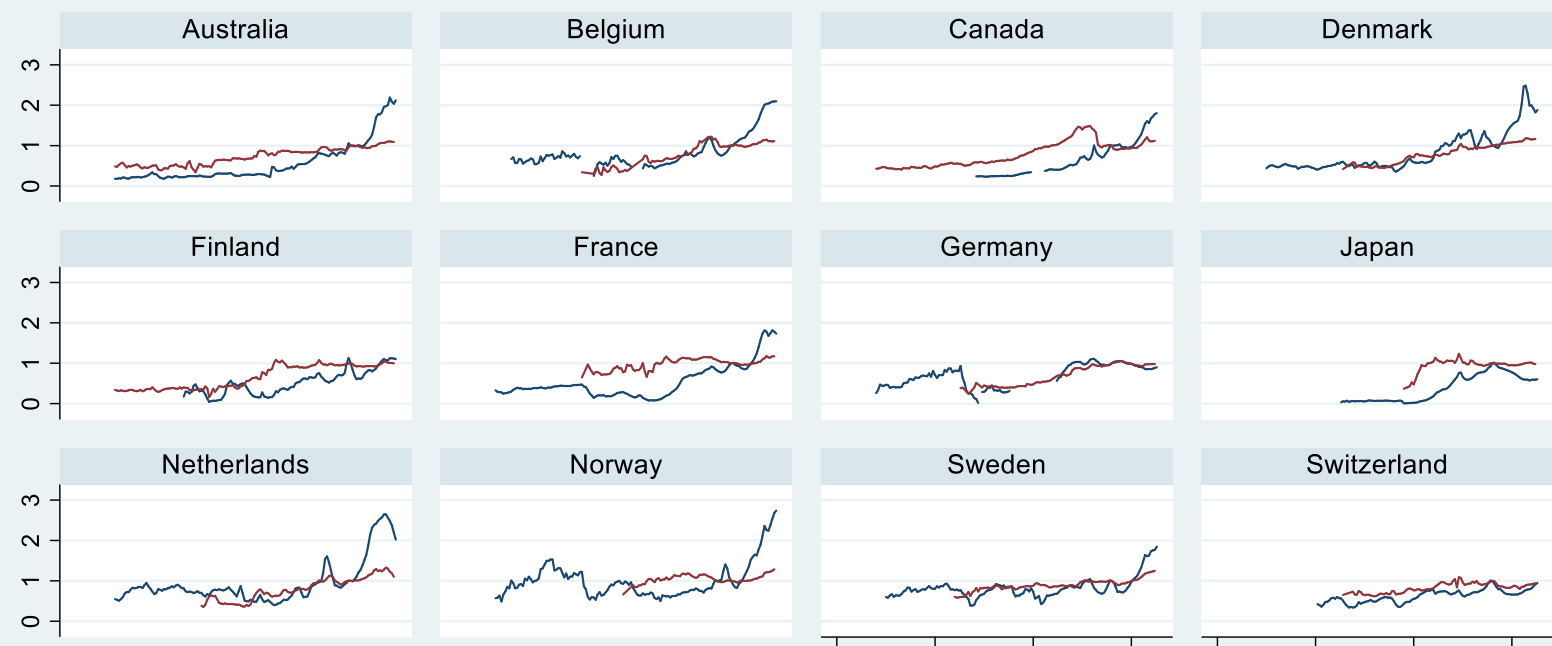

Switzerland
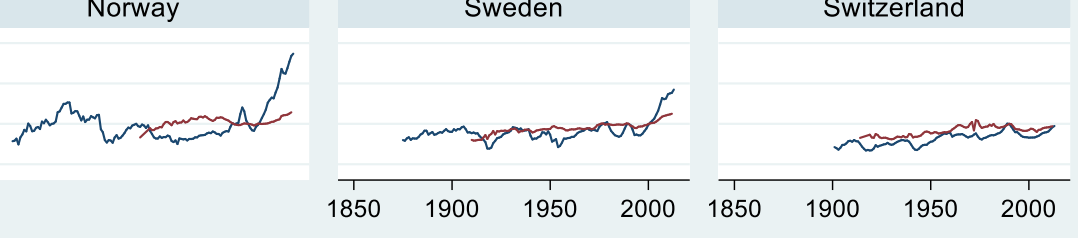

UK
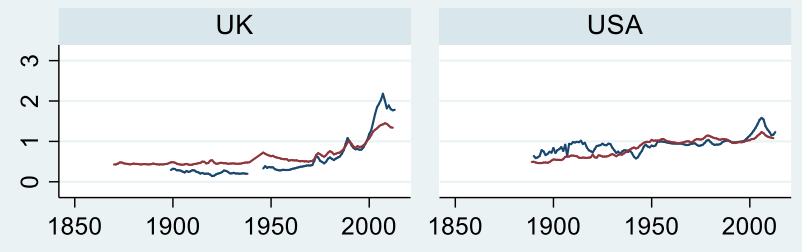

\section{Real House Prices}

\section{Real Construction Costs}

Note: The lines show indices equal to 1 in 1990. They are interrupted when data are missing, as is the case for house prices in many countries during World War I and II. The values before and after the interruptions are nevertheless comparable. The historical series are sourced from Knoll et al. (2017[6]); real house prices from 1990 to 2018 come from the OECD Economic Outlook November 2019 database.

Source: (Knoll, Schularick and Steger, 2017[6]) , (OECD, 2019[7]) and OECD calculations. 
Under current policies, though subject to uncertainty, the scenarios suggest that further sizeable increases in real house prices would likely materialise, hurting affordability. House prices are projected to rise by more than disposable incomes in countries where policy settings restrict supply and population increases are substantial. Simulations suggest that house prices could rise by more than three years of disposable income in Australia, Denmark, the Netherlands, Sweden and the United Kingdom. This surge in real house prices would make dwellings difficult to afford for many more people. To give just two examples: the fraction of people for whom an average $100 \mathrm{~m}^{2}$ home is worth more than 15 years of disposable income would rise from $43 \%$ today to $86 \%$ in 2050 in Sweden and from $67 \%$ to $91 \%$ in Australia.

Several scenarios show that reforms of housing taxation, land-use governance and rent control could improve housing affordability considerably. Phasing out mortgage interest relief offers considerable potential to ease price pressures. Simulations suggest that average real house prices could fall by nearly or more than two years of household disposable income below where their baseline trajectory in Belgium, Denmark, Norway and Sweden. Such a reform would also contribute to greater income equality, as mortgage interest relief typically benefits the well-to-do more, as they are better placed to access the mortgage market. However, lower prices imply less housing investment and a smaller housing stock. Streamlining land-use governance to the lowest reading of the indicator (a level on average empirically linked with robustly responsive housing supply) reduces simulated house prices by more than half a year of income in New Zealand and the United Kingdom. Relaxation of rent control to the third most flexible setting reduces prices by more than four months of income in Australia, Ireland, Luxembourg and Switzerland and more than a year of income in Sweden, which currently has a highly restrictive rent-control regime. In the long term, by comparison with the baseline, lower house prices imply lower rent levels, even if rents may rise temporarily after rent controls are eased.

The paper is structured as follows. Section 2 describes the framework used to project housing supply and prices over the long term. Section 3 reports the baseline scenarios, which are based on unchanged policies, before discussing the projected impacts of changes to mortgage interest relief, land use governance and rent level regulation. The final section produces new evidence on the take-up of online short-term rentals and discusses the likely consequences of potential further online platform incidence using illustrative scenarios produced with the simulation framework.

\section{A framework for long-term projections of house prices and investment}

The empirical framework for the scenarios builds on two recent OECD studies, which developed demand and supply elasticities for national and regional housing markets in a panel of OECD countries (Cavalleri, Cournède and Özsögüt, 2019 [1]; Bétin and Ziemann, 2019 $\left.{ }_{[2]}\right)$. In this housing demand and supply framework, changes in demographics, per capita income or real interest rates generate shifts in housing demand, which in turn affect house prices. Developers then adjust supply according to price signals and construction costs. Income elasticities of house prices and price elasticities of residential construction jointly determine how much of a change in demand feeds into prices and how much into construction. The housing stock depends on depreciation, which is lower for housing than for most other types of capital and new construction. The resulting changes in the housing capital stock feed back into house prices. In addition, wealth effects and second-round income effects from the construction sector could spur additional housing demand. The resulting stock-flow framework (Figure 3 ) is consistent with a vast literature following the seminal contribution by di Pasquale and Wheaton $\left(1994_{[8]}\right)$. 


\section{Figure 3. A stock-flow framework for housing}

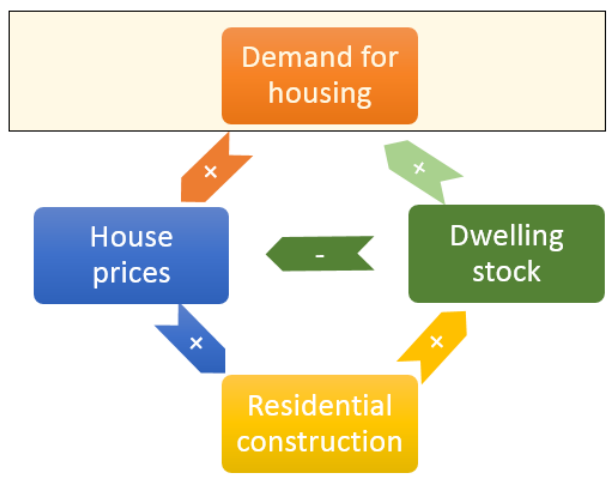

Several housing policies have a considerable effect on the efficiency and the functioning of housing markets. There is, for instance, ample evidence that eliminating the mortgage interest deduction causes house prices to decline, reduces the housing stock, increases homeownership, decreases mortgage debt and improves welfare (Sommer and Sullivan, 2018[9]; Alpanda and Zubairy, 2016 $\left.{ }_{[10]}\right)$. Recent investigations confirm these findings and find that a lower marginal effective tax rate (METR) on residential property, which typically stems from larger interest payment deductions, increases the income elasticity of house prices (Cavalleri, Cournède and Özsögüt, $\left.2019_{[1]}\right)$. Conversely, this result suggests that reducing income tax breaks for home buying offers the benefit that an increase in demand will have a smaller effect on house prices.

The governance of land-use varies markedly across OECD countries (OECD, 2017[11]). A high degree of decentralisation of land-use decisions and a lot of responsibility overlaps are empirically associated with high rigidity of housing supply (Bétin and Ziemann, 2019 ${ }_{[2]}$; Cavalleri, Cournède and Özsögüt, 2019 $9_{[1]}$ ). The link from high decentralisation of land-use responsibilities to less flexible supply is consistent with the home-voter hypothesis, which predicts that homeowners turn to local politicians to protect the value of their housing investment by restricting the additional development of land (Fischel, 2001[12]; Gyourko and Molloy, $\left.2015_{[13]}\right)$. Responsibility overlaps are associated with more stringency and delay as several levels of government can veto projects and political economy pressures intensify (Gyourko, Saiz and Summers, $\left.2008_{[14]}\right)^{2}$

Furthermore, strict rental market regulation has been found to inhibit new construction by reducing the incentives to invest in rental housing due to lower rental revenues and greater difficulty to sell real estate properties due to stringent tenant regulations (Kholodilin and Kohl, 2020[15]). Diamond, McQuade and Qian $\left(2019_{[16]}\right)$ estimate that rent control in San Francisco reduces housing supply by as much as 15 percentage points. Cavalleri, Cournède and Özsögüt $\left(2019_{[1]}\right)$ find that the house price elasticity of residential construction is considerably lower in the case of stringent rental market regulation. In the long run, higher house prices and lower supply impede access to home-ownership, increase both rents and home prices, and are thereby likely to offset short-term benefits for rent-paying low-income households. The supply distortion stemming from tight rent regulation can also exacerbate speculative bubbles, resulting in greater economic instability (Cournède, Sakha and Ziemann, 2019[17]). Tight rent control can also contribute to a homeownership bias.

\footnotetext{
${ }^{2}$ An opposite relationship, not quantified in this paper, links more decentralisation of responsibilities over property taxes to greater housing supply flexibility (Oszogut, 2020[46]). The reason is that local governments have greater incentives to encourage housing development where they have more leeway to collect taxes on residential property (Phillips, 2020[47]).
} 
The research presented in this paper uses newly developed indices for the governance of land-use policy (Cavalleri, Cournède and Özsöğüt, 2019 ${ }_{[1]}$ ) and the restrictiveness of rent control, both derived from the 2019 OECD Questionnaire on Affordable and Social Housing (QuASH). The governance indicator assesses the organisation of land-use decision-making processes across different levels of government. Higher values of the indicator reflect more overlap and/or more decentralisation. The indicator is calculated by summing the values of importance for the corresponding level of government in the land-use decisionmaking process (from none $=0$ to very high $=5$ ) across the three administrative levels and weighting the values by the level of decentralisation (metropolitan=1, municipal=2, district=3).

The rent control index reflects several dimensions restricting the landlord's ability to set and increase rents. The indicator summarises the extent of restrictions on setting the rent revel initially, up-dating it and passing costs (such as renovation expenses) on tenants. The indicator corresponds to the legislation applicable to the country; sub-national entities may apply more restrictive regimes, implying a degree of within-country heterogeneity. Figure 4 depicts these indicators for 27 countries for which all indicators are available (see Appendix A for why some countries are missing).

\section{Figure 4. Selected housing policy indicators}
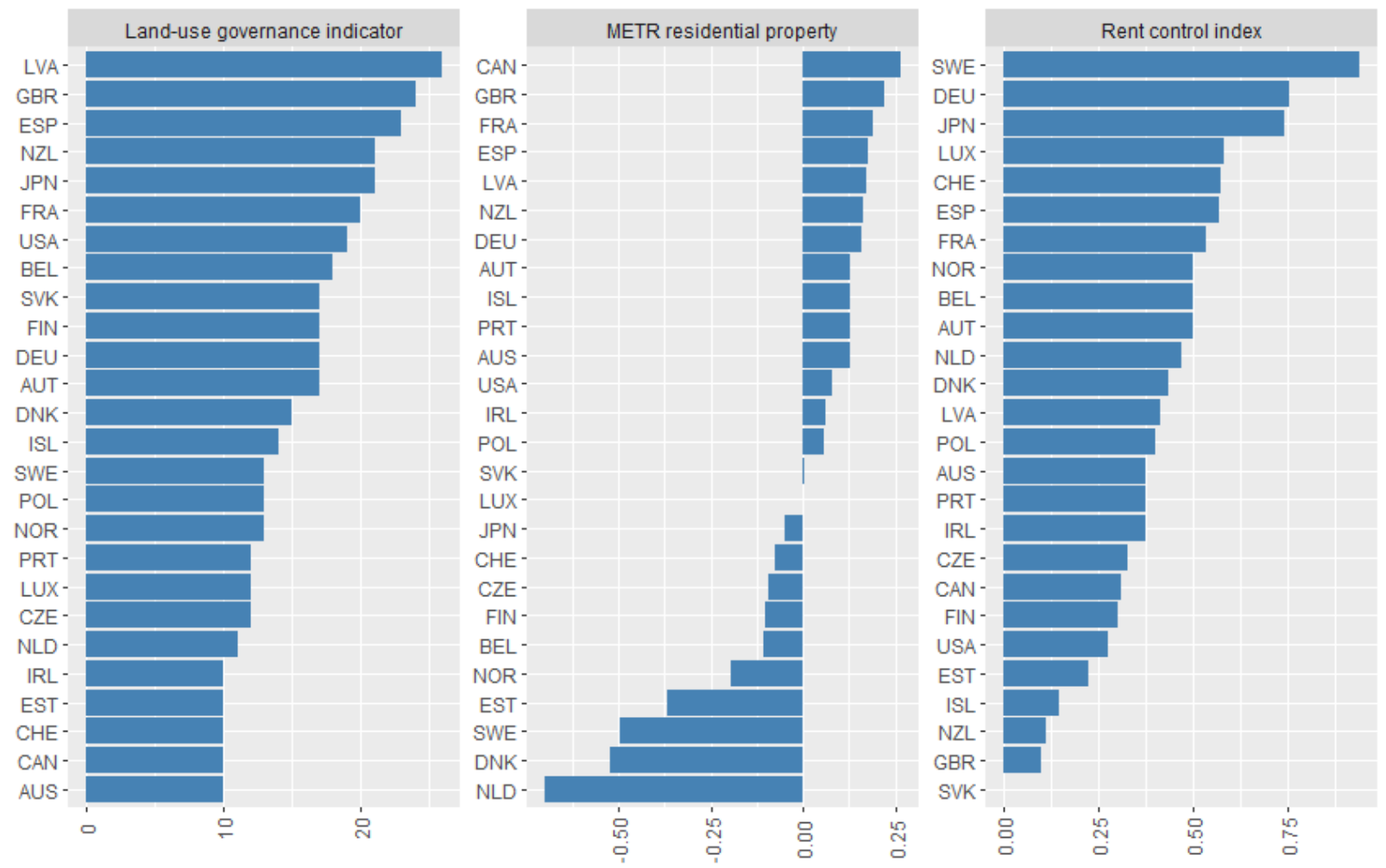

Note: The governance of land-use indicator ranges from 0 (least restrictive) to 30 (most restrictive) according to answers to the 2019 OECD Questionnaire on Affordable and Social Housing. METR stands for "marginal effective tax rate" for owner-occupied, debt-financed housing investments. The indicator is a preliminary 2019 update of (OECD, 2018), "Taxation of Household Savings". The rent control index ranges from 0 (no restrictions) to 1 (all types of restrictions) according to answers to the 2019 OECD Questionnaire on Affordable and Social Housing and is back-casted using DIW's rent control index (https://www.remain-data.org/).

Source: OECD calculations. 
The specification of the demand equation builds on Cavalleri, Cournède and Özsöğüt (2019 $\left.{ }_{[1]}\right)$ and includes fundamental housing demand drivers as well as an interaction term between household disposable income and the marginal effective tax rate of property taxation (METR) on debt-financed owner-occupied residential property capturing the tax bias in favour of investment in housing: ${ }^{3}$

$$
\ln P_{t}=\alpha_{0}+\alpha_{1}\left(\ln Y_{t}-\ln P O P_{t}\right)+\alpha_{2} \ln P O P_{t}+\alpha_{3} r_{t}+\alpha_{4} \ln S_{t-1}+\alpha_{5}\left(\ln Y_{t} * \tau_{t}\right)+\delta_{c}+\varepsilon_{t}
$$

with $P$ denoting quality-adjusted real house prices, $Y$ real disposable income, $P O P$ the country's population, $r$ the real interest rate for mortgage loans, $S$ the dwelling stock, $\tau$ the effective rate of property taxation for home-owned, debt-financed housing and $\delta_{c}$ a set of dummies measuring country-fixed effects. The estimated coefficients (Table 1 ) are close to the estimation results of Cavalleri, Cournède and Özsöğüt $\left(2019_{[1]}\right)$. They were re-estimated for two reasons. The first is to ensure full alignment between the estimation and simulation datasets. The second is that causal inference and simulations call for different estimation strategies: especially, time fixed effects are useful for causal inference but problematic for simulations, where the continuation of past trends in the time fixed effects would mean that unexplained forces could drive the projections.

Table 1. Price equation

Dependent variable: Real house prices

\begin{tabular}{l|c|c|c|c}
\hline \multicolumn{1}{c|}{ Variable } & Coefficient & Std. Error & t-Statistic & Prob. \\
\hline Log real per capita disposable income & 1.491 & 0.048 & 30.772 & 0.000 \\
\hline Real interest rate & -0.578 & 0.126 & -4.593 & 0.000 \\
\hline Log dwelling stock (housing units) & -0.808 & 0.061 & -13.138 & 0.000 \\
\hline Log disposable income $x$ tax rate on housing & -0.904 & 0.070 & -12.910 & 0.000 \\
\hline Log population & 2.132 & 0.106 & 20.025 & 0.000 \\
\hline Periods included: & 148 & Adjusted R-squared: & 0.753 \\
\hline Cross-sections included: & 27 & Cross-section fixed effects: & Yes \\
\hline Total panel observations: & 2844 & Time-fixed effects: & No \\
\hline
\end{tabular}

Note: The panel runs from 1981Q1 to 2017Q4 and includes 27 countries. The dwelling stock is lagged by 1 year.

Source: OECD calculations.

The dwelling stock depreciates, albeit at a slower pace than machinery and equipment or most other productive capital, and grows over time with residential investment. The latter depends on expected capital gains from housing investments, that is the sum of future streams of rental income (imputed or not) discounted by the user cost of capital. Current house prices serve as a proxy for the sum of discounted future rents, and construction costs measure the labour and material costs of the acquisition. Moreover, a range of housing policies are likely to affect the mechanisms through which additional demand feeds into new supply of housing including land-use policies and rental market regulation.

3. Note that the METR takes into account the effects of taxes on immovable property as well as housing-related provisions in the rest of the tax code (OECD, 2018[42]). The METRs used in the analysis are updates of OECD (2018[42]) and are preliminary. 
Natural and man-made constraints to housing supply that are not necessarily related to policy also play a key role in the functioning of housing markets. Indeed, geographical constraints reduce supply elasticities (Saiz, 2010[18]; Bétin and Ziemann, 2019[2]; Hilber and Vermeulen, 2016[19]). To capture the presence of natural and density constraints, an indicator of land availability is added to the set of explanatory variables. The resulting econometric specification is as follows:

$\ln I_{t}=\beta_{0}+\beta_{1} C C_{t}+\beta_{2} P_{t}+\beta_{3}\left(\ln P_{t} *\right.$ Land $)+\beta_{4}\left(\ln P_{t} * L U R I\right)+\beta_{5}\left(\ln P_{t} * R C I_{t}\right)+\beta_{6} R C I_{t}+\delta_{c}+\varepsilon_{t}$

Variable I represents real residential investment, $C C$ real construction costs (here proxied by the national accounts deflator of residential investment), Land represents the share of a country's total artificial surfaces over total developable land in 2014, LURI is the land-use restrictiveness index, $R \mathrm{Cl}$ an index of rent control and $\delta_{c}$ country fixed effects. Table 2 shows the estimated coefficients.

Table 2. Investment equation

Dependent variable: Residential housing investment (volume)

\begin{tabular}{l|c|c|c|c}
\hline \multicolumn{1}{c|}{ Variable } & Coefficient & Std. Error & t-Statistic & Prob. \\
\hline Construction costs & -0.376 & 0.035 & -10.664 & 0.000 \\
\hline Real house prices & 0.721 & 0.016 & 44.174 & 0.000 \\
\hline Real house prices $x$ Available land & 0.089 & 0.006 & 14.414 & 0.000 \\
\hline Real house prices $x$ Land use policy & -0.010 & 0.002 & -4.998 & 0.000 \\
\hline Real house prices $x$ Rent control & -0.219 & 0.055 & -3.986 & 0.000 \\
\hline Rent control & -0.087 & 0.044 & -1.970 & 0.049 \\
\hline Periods included: & 152 & Adjusted R-squared: & 0.991 \\
\hline Cross-sections included: & 27 & Cross-section fixed effects: & Yes \\
\hline Total panel observations: & 3346 & Time-fixed effects: & No \\
\hline
\end{tabular}

Note: The panel runs from 1980Q1 to 2017 Q4 and includes 27 countries. Construction costs are proxied by the residential housing investment deflator from the national accounts and deflated by the consumer price index. Real house prices are quality-adjusted indices of the average dwelling price deflated by the consumer expenditure deflator.

Source: OECD calculations. 
The estimation of dwelling stocks is a major challenge in this set-up. On the one hand, the use of housing units reduces measurement errors and assures comparable results across countries. On the other hand, it also requires the conversion of residential investment into housing units to build the housing stock over time. To do so, the dwelling stock accumulation equation (3) is rewritten as (4). The net rate of change in the dwelling stock is regressed on the ratio of dollar-investments per existing housing units:

$$
\begin{aligned}
& S_{t}=\left(1-\delta_{c}\right) S_{t-1}+\gamma_{c} I_{t} \\
& \frac{S_{t}}{S_{t-1}}-\left(1-\delta_{c}\right)=\gamma_{c} * \frac{I_{t}}{S_{t-1}}+\varepsilon_{t}
\end{aligned}
$$

$\delta_{c}$ are country-specific depreciation rates obtained using an inverted perpetual inventory method based on KLEMS sectoral data for investment and capital stocks of residential structures in the real estate sector. ${ }^{4}$ Country-specific parameters $\gamma_{c}$ are estimated using standard OLS techniques. Equation (3) maps housing investment (chained volume prices) into new dwelling units. The obtained dwelling stock then feeds back into prices in equation (1).

\section{Future trends in housing affordability: Baseline and policy scenarios}

\subsection{Baseline}

The system of equations (1) - (3), iterated over time, allows projecting house prices, residential investment and dwelling stocks based on macroeconomic and policy assumptions. Population, disposable income, interest rates and inflation are taken from OECD's long-term projections (Johansson et al., 2013 [20]; Guillemette, De Mauro and Turner, 2018[21]; Guillemette, 2019[22]). The baseline scenario is a no-policychange scenario meaning that the policy indicators observed in 2017 are held constant over the projection horizon up to 2050.

Solving the iterative model yields baseline projections for house prices, residential investment and the dwelling stock until 2050. Figure 5 depicts the changes in the housing stock, real house prices as well as house-price-to-income ratios between 2020 and 2050. Under current policies, price-to-income ratios are projected to increase substantially in Luxembourg and Sweden and, to a lesser extent, in Australia, New Zealand, Ireland, Denmark, Norway, the Netherlands and the United Kingdom. The three Scandinavian countries levy low marginal effective tax rates on residential property (Figure 4), which increases the income elasticity of house prices. New Zealand and the United Kingdom have land-use policy settings that weigh on supply elasticities and thereby weaken the feedback loop from higher prices through more construction to house price moderation. Australia, Luxembourg and Sweden also stand out as the three countries with the most dynamic population growth over the projection horizon (Figure 7). Conversely, price pressures are projected to ease in several countries including Latvia, Portugal, Poland, Japan or Italy on the back of shrinking populations.

4. Equation (4) uses country-specific depreciation rates calculated over 1995 to 2015 . The volume indices of residential investment are converted into dollars using constant market exchange rates. These conversions are made to ensure that the estimated $\gamma_{c}$ coefficients share a common scale; the conversions, however, do not influence the results since the coefficients are heterogeneous and the error term heteroskedastic. 
Figure 5. Baseline changes in the housing stock, house prices and price-to-income ratios

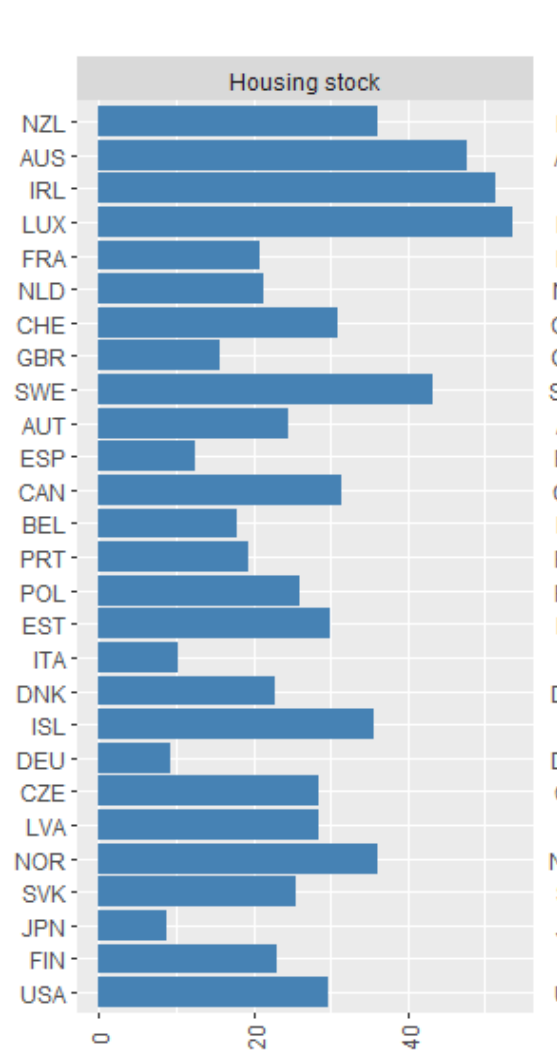

Change between 2020 and 2050
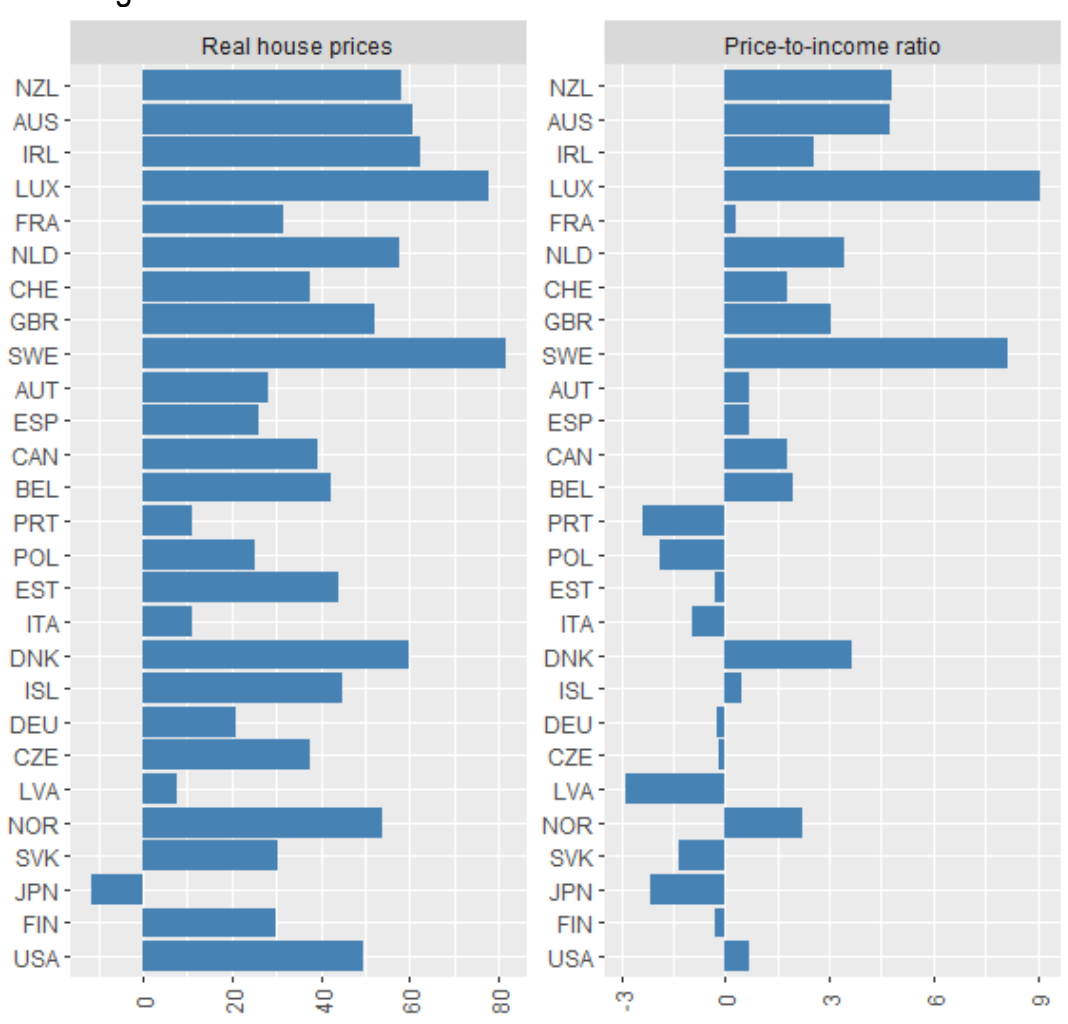

Note: Percentage point changes for "housing stock" and "real house prices"; additional number of years of disposable income required to buy a $100 \mathrm{~m} 2 \mathrm{dwelling}$ in the case of "price-to-income ratios". All estimates and simulations are computed with quality-adjusted real house price indices. The price levels of $100 \mathrm{~m} 2$ dwellings in 2017 are used to scale the results so that they can be compared to the levels of household income. Countries are ranked by price-to-income ratios in 2017 from highest (New Zealand) to lowest (USA) according to Bricongne, Turrini and Pontuch $\left(2019_{[4]}\right)$ (see Figure 1). Housing stock and real house price projections are obtained by iterating equations (1)-(3), while exogenous variables (income, population, interest rates, construction costs) are taken from OECD's long-term projections (e.g. Guillemette (2019[22])).

Source: OECD calculations.

Variations in house prices have also important consequences for income inequality. Under current policies, the projected increase in price-to-income ratios is accompanied by a substantial reduction in the percentage of the population able to buy a house in the next 30 years. For the sake of illustration, the fraction of people for whom the price of a $100 \mathrm{~m}^{2}$ house is lower than 15 years of disposable income is projected to drop from $57 \%$ to $14 \%$ in Sweden and from $23 \%$ to $9 \%$ in Australia, respectively (Figure 6). 


\section{Figure 6. Housing and inequality}

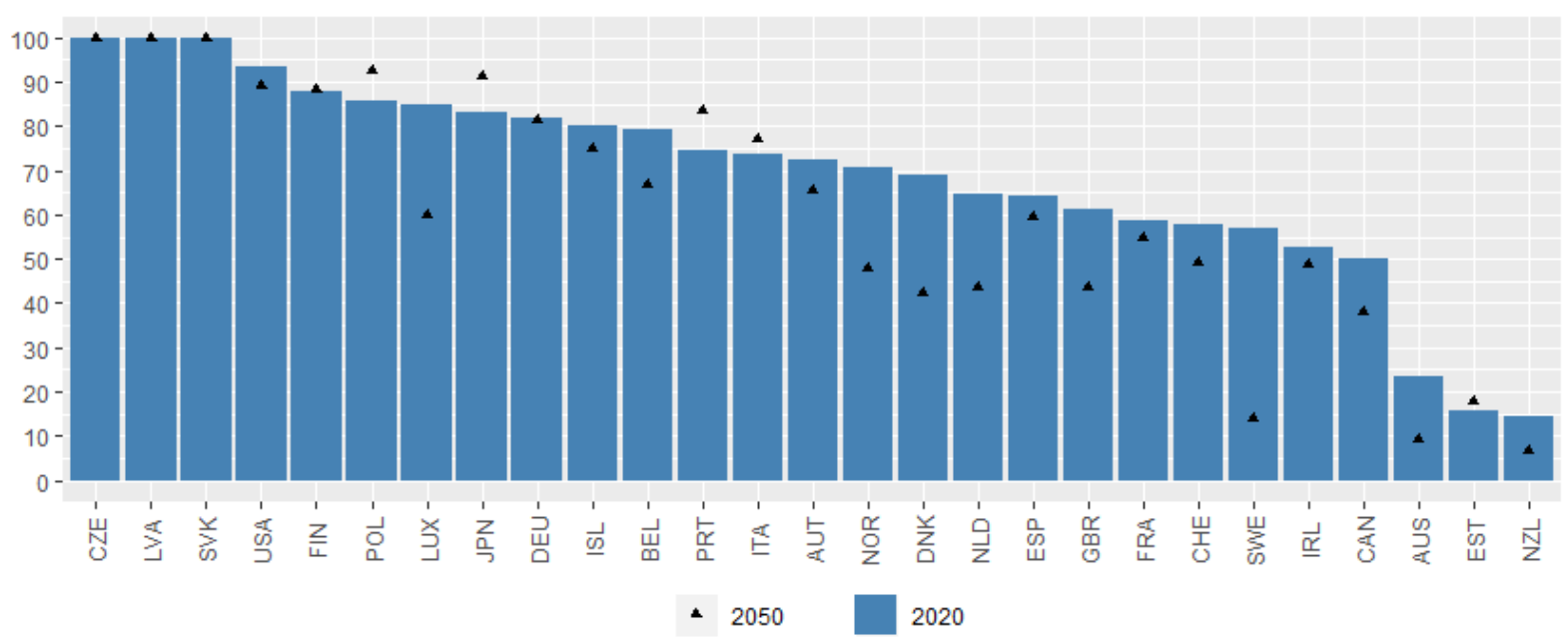

Note: Bars and triangles depict the percentage of the population that can afford to buy a house using 15 years (or less) of disposable income. Based on the income deciles as of 2018.

Source: OECD calculation

The projections of fundamental housing demand drivers depicted in Figure 7 are subject to considerable uncertainty. To illustrate the sensitivity of the baseline results for house prices to changes in fundamental demand drivers, Figure 8 shows the percentage point change in real house prices in 2050 if per real capita income and population rise faster or if interest rates are lower than assumed in the baseline scenario. For income and population, an additional growth of 10 basis points per quarter (roughly 10 percentage points over 25 years) with respect to the baseline is assumed, while interest rates are assumed to be permanently lower by 200 basis points, again, with respect to the baseline scenario. The evolution of fundamentals could also be less favourable, with the associated symmetric dampening effects. 
Figure 7. Past and projected developments of housing demand drivers
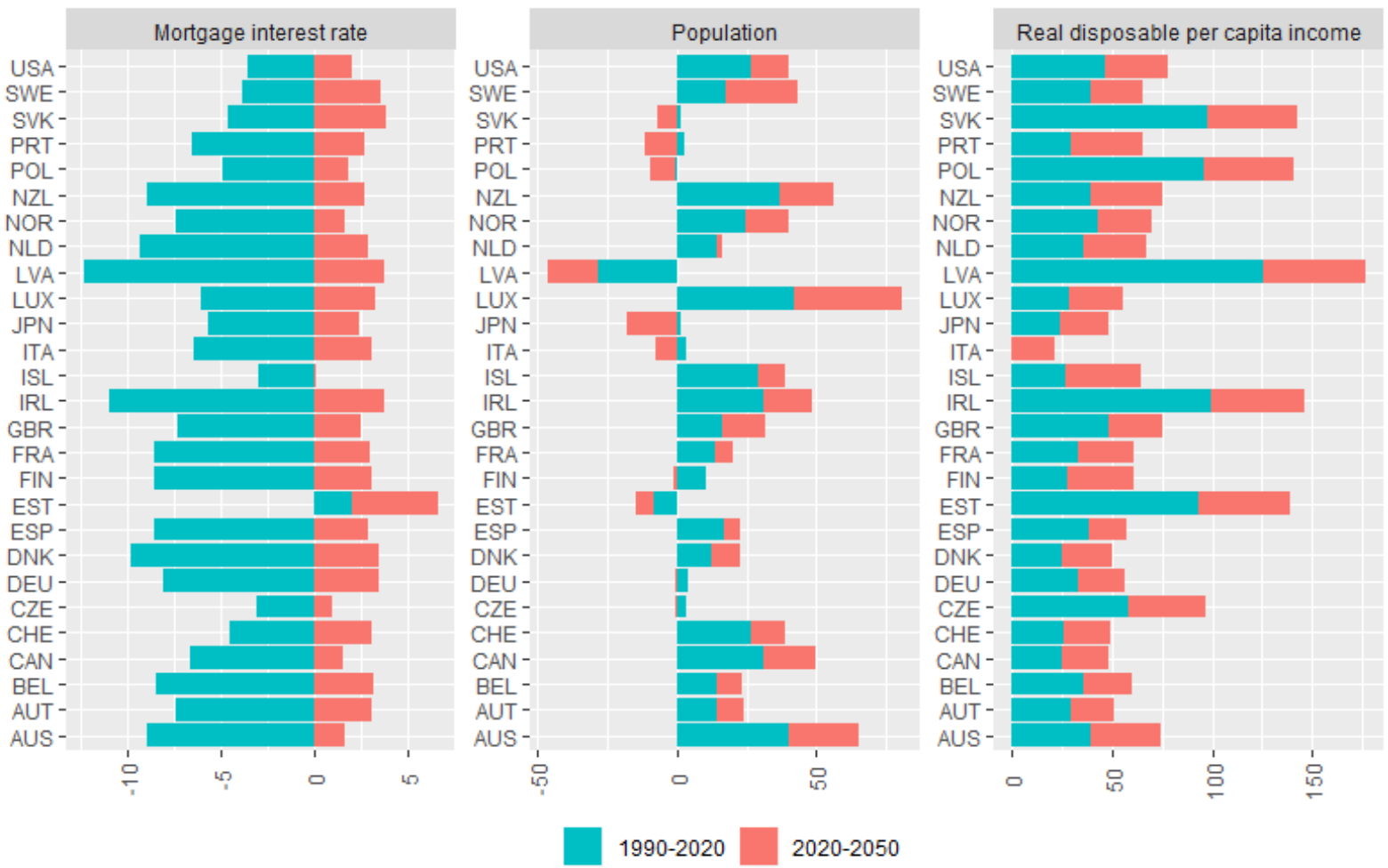

Note: Bars depict percentage point changes for each period.

Source: OECD calculations.

Additional pressures are simulated to increase house prices between 10 and 18 percentage points in the higher income growth scenario, between 20 and 27 percentage points in the high-population scenario and by roughly 1 percentage point in the low-interest rate scenario. Even though uncertainty surrounds these projected figures, the differences underline that, over the long term, population and income are powerful drivers of house prices. Real interest rates appear to play a more muted role at such long-term horizons, in contrast with their strong influence at shorter horizons (Ahrend, Cournède and Price, $2008_{[23]}$ ). Country differences in the sensitivity to these shocks shed light on differences in the income elasticities of house prices (in the case of the higher income and higher population scenario, see equation (1)) and house price elasticities of residential investment (supply elasticities). The latter determines the size of the offsetting feedback effect of more residential investment in response to higher house prices (see equation (2)). Indeed, as expected, countries with high-income elasticities due to low marginal effective property taxation (Denmark, Sweden) exhibit the highest pass-through of additional housing demand to higher house prices arising from higher income. 


\section{Figure 8. House price sensitivity with respect to changes of fundamental demand drivers}

Difference of real house prices from baseline in 2050 (in per cent)
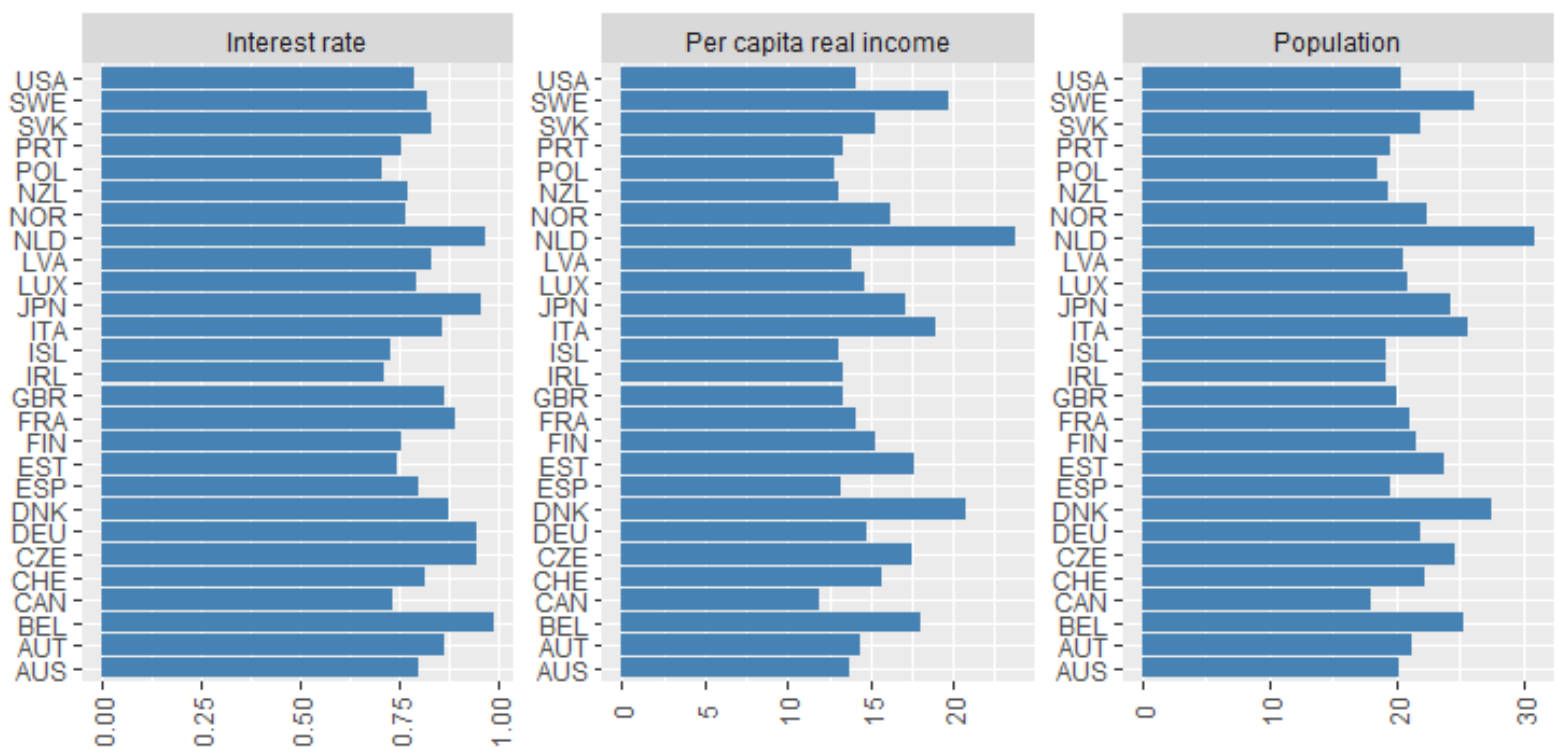

Note: The table shows percentage point differences to baseline house prices in 2050 derived from alternative scenarios for income and population (resp. 10 basis points additional quarterly growth rates with respect to baseline) and interest rates (-200 basis points with respect to baseline) over the projection horizon (2020 to 2050).

Source: OECD calculations.

\subsection{Housing policy scenarios}

Using the same empirical framework, policy scenarios focus on streamlining land-use governance, easing rent control and eliminating mortgage interest relief.

- It is assumed that countries converge to the lowest observed level of the land-use governance indicator observed in Australia, Canada, Estonia, Ireland and Switzerland. Lower readings of the land-use governance indicator have been empirically linked to more responsive housing supply (Cavalleri, Cournède and Özsögüt, 2019[1]).

- For rent control, the assumption is that countries move to the level of New Zealand (except for the United Kingdom and Slovakia where the indicator suggests regulation is more flexible than in the United States).

- For the tax scenario, it is assumed that countries remove mortgage interest relief from their tax code, which largely explains the heterogeneity of the METRs. Indeed, all countries with currently negative METRs would exhibit a positive METR in the case of eliminating mortgage interest relief. The largest impacts of such a reform would be felt in the Netherlands, Denmark, Sweden and Estonia.

Figure 9 illustrates the estimated effect of the various scenarios on house price to income ratios by 2050 while time series for dwelling stocks and real house prices are delegated to Appendix $B$. The most sizeable improvements in the affordability of housing are projected to be achieved by the Netherlands and Sweden in the scenarios where mortgage interest relief is removed. Doing so reduces house prices by making house prices less sensitive to income changes. In the scenario for Sweden, the number of years of income required to buy a $100 \mathrm{~m}^{2}$ dwelling falls by more than 6 years, with considerable positive consequences on inclusiveness. The percentage of the population able to purchase a house with 15 years of income in 2050 is projected to reach $44 \%$ following the removal of mortgage interest relief against $14 \%$ in the no-policy- 
change scenario. In the short term, removing mortgage interest relief would make homeownership more difficult to afford for middle-class households through the direct effect on their budget. However, the mechanisms illustrated by the simulations mean that this effect fades and then reverses over time as house prices become lower than they would otherwise have been, especially so in countries where housing supply is more rigid.

Swedish households would also benefit the most in terms of housing affordability from easing rent control. In the long term, residential construction is projected to expand by more than $25 \%$ in a hypothetical illustrative scenario where rent control becomes as deregulated as in the United States. The result is that housing stock becomes $13 \%$ larger by 2050 . More supply of housing implies lower real house prices, which enhances affordability. Indeed, projections suggest that this hypothetical illustrative scenario of rent control reduces the level of real house prices in 2050 by 1.5 years of disposable income compared with a baseline of unchanged policies.

Streamlining land use governance in directions that have been found linked with more flexible supply also offers potential to improve affordability. Moving towards framework where land use decisions are made with consideration for the whole metropolitan area, rather than immediately neighbouring areas, and that minimise overlaps in decision making power, has the potential to reduce the long-term ratio of house prices to incomes. For instance, residential investment in the "streamlined land-use policy" scenario increases by more than $11 \%$ in New Zealand with respect to the baseline scenario : by 2050 , this leads to $7 \%$ more homes, an expansion in supply that is projected to reduce house prices by more than a year of household disposable income.

Simulating a package combining all these changes suggests that such a broad housing reform strategy could improve long-term housing affordability by more than two years of disposable income in six countries: Belgium, Denmark, Estonia, Netherlands, Sweden and Switzerland (Figure 9, bottom panel). The simulation framework involves non-linear effects: for instance, taxation influences prices, which then in the following period interact with rental regulation to drive construction. However, these non-linear effects are quantitatively small, so that the effect of the reform package is close to the sum of the effects of its components. 
Figure 9. Simulated impact of reform scenarios on price-to-income ratios by 2050
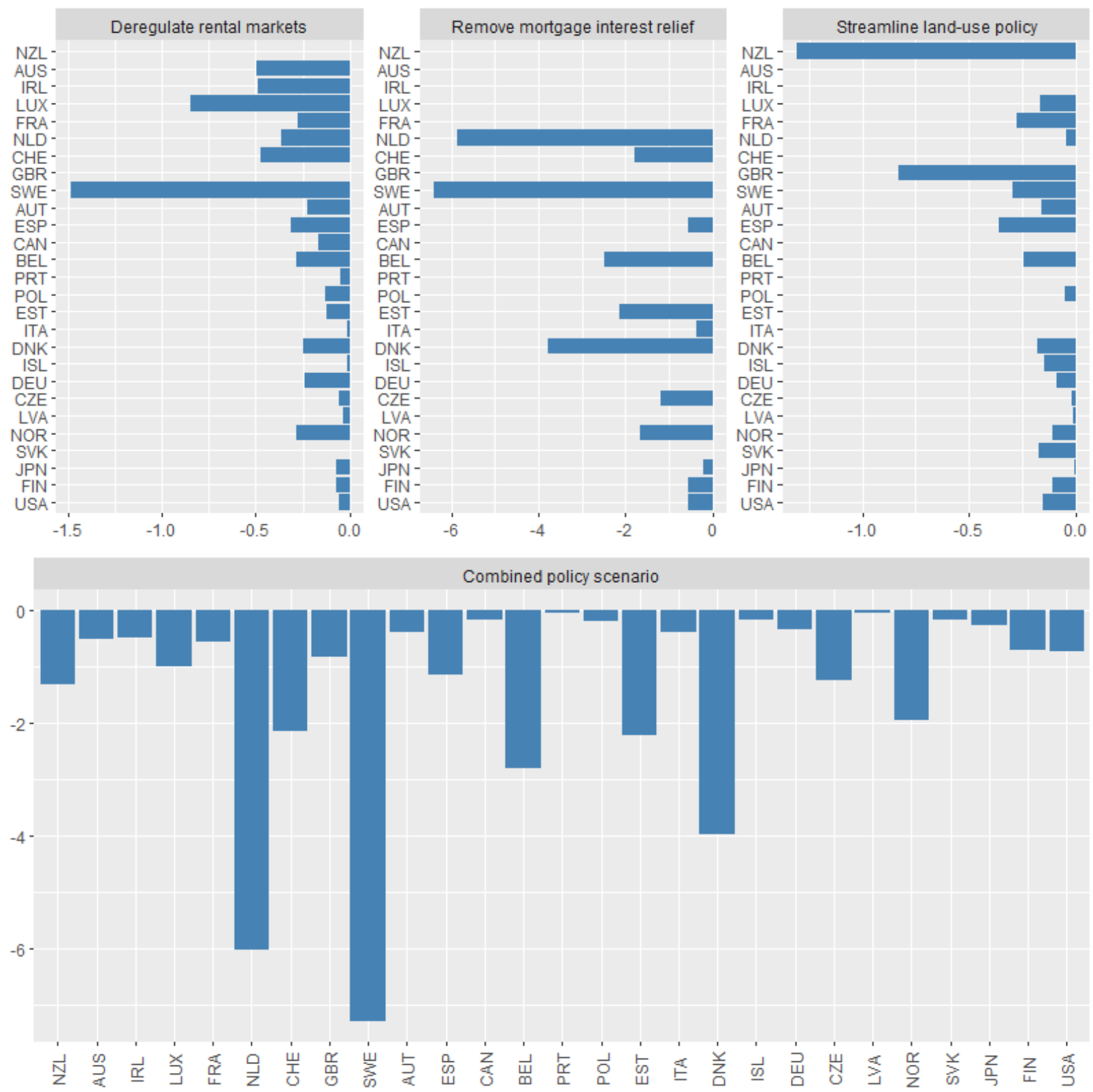

Note: No bar signifies an absence of mortgage interest relief and, in the case of the rent control and land-use scenarios, that the country does not implement a reform as it was already less or as restrictive as the benchmark country (GBR, SVK and USA in the case of rent control; CHE, CAN and IRL in the case of land-use governance). The chart shows countries in the same order as Figure 1, that is to say, price-to-income ratios in 2017 from highest (New Zealand) to lowest (USA) according to Bricongne, Turrini and Pontuch (2019[4]). All estimates and simulations are computed with quality-adjusted real house price indices. The price levels of $100 \mathrm{~m} 2$ dwellings in 2017 are used to scale the results so that they can be compared to the levels of household income.

Source: OECD calculations. 


\section{Digital home sharing platforms}

Over the past decade, online home sharing has made rapid inroads in many cities, especially touristic destinations. The major player in the home sharing market is Airbnb, though other companies such as Booking.com and HomeAway are also offering such services. Since its creation in 2008, Airbnb experienced exponential growth: it went from 50000 listings in 2010 to more than 7 million listings in late 2019 across 100000 cities around the world, becoming the world's largest home-sharing platform (Guttentag, 2015[24]).

Assuming online home-sharing returns over the coming three or five years once the impact of COVID-19 fades, the rapid growth of home-sharing platforms like Airbnb is likely to influence the long-term future of housing markets. It brings opportunities but also raises questions about the potential impact on local communities as well as important policy challenges (see Box 2). In particular, the rapid growth of Airbnb raises concerns about housing affordability. With the advent of Airbnb, housing units that were only available on the local residential market become potential short-term Airbnb listings, with the effect of increasing the supply of rooms in the hospitality sector (though presumably also replacing part of conventional hotel capacity), while reducing it in the long-term rental market. If supply cannot easily respond to this additional demand, negative consequences can develop in terms of reduced housing affordability, displacement of local residents away from the centre of activity and gentrification (Wachsmuth and Weisler, 2018[25]).

Despite the public debate on the effects of Airbnb on local communities that was growing before the COVID-19 crisis, there is scant cross-country empirical evidence on its effect on housing markets. ${ }^{5}$ To shed some light on this matter, this study builds on the results from the previous section and simulates the long-term impact of an expansion of holiday rentals on house prices. For this simulation exercise, the average incidence of Airbnb in cities is measured using data from two sources. The website InsideAirbnb.com provides Airbnb listings. These listings are combined with geo-spatial data on population taken from the Global Human Settlement Layer (GHSL) dataset (see Box 2 for a detailed description of the data).

The average incidence of Airbnb in cities is computed by the ratio between the number of occupants of Airbnb accommodations listed for more than 90 days per year and the number of people living in the city. Only such long-term rentals effectively reduce supply for local rental and owner-occupied housing. Figure 10 reports the values of this indicator for 36 cities for the earliest and latest available year. On average, Airbnb crowded out $1.73 \%$ of local housing supply in 2019 , ranging from $0.3 \%$ in Istanbul to $9 \%$ in Venice. Interestingly, following changes in holiday rental regulations, the incidence of long-term holiday rentals dropped recently in cities such as Amsterdam, Copenhagen, Paris and Berlin (see Box 2 and Appendix C).

5. The existing studies focus mostly on a single country or cities: see for example Barron, Kung and Prosepio (2018[43]) for an empirical study of the effect of Airbnb on residential house prices and rents in the United States, Lee (2016[27]) for an analysis of the housing market in Los Angeles, Horn and Merante (2017 ${ }_{[44]}$ ) for a study of Boston, Wachsmuth and Weisler $\left(2018_{[25]}\right)$ for New-York City, and Pettit et al. (2018[45]) for a report on the potential impact of new technologies on the Australian housing market. 
Figure 10. Occupants of flats listed on Airbnb for three months or longer relative to city population

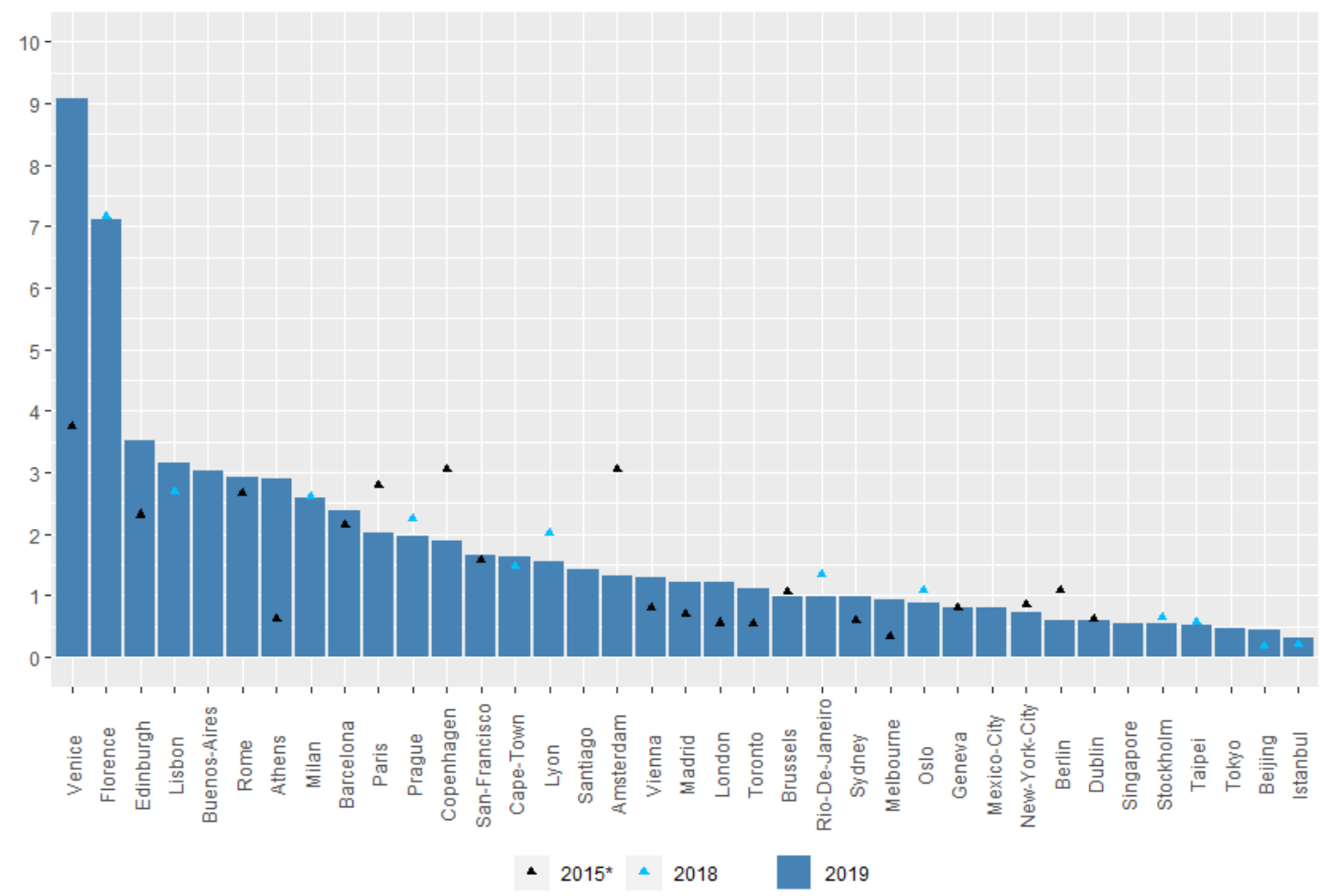

Note: The $y$-axis is expressed in percentage. The first available time value is 2016 for Copenhagen, Dublin and Geneva and 2017 for Rome. The proxy for the number of people living in an Airbnb accommodation is computed assuming that on average an entire flat is inhabited by four persons, a private room by two persons and a shared room by one person.

Source: OECD calculation based on data from InsideAirbnb.com and GHSL.

The simulation exercise assumes a 5 per cent reduction in the primary-residence housing market induced by holiday rentals, which is more than observed in the majority of cities considered but is still well below the incidence in touristic cities such as Florence or Venice. ${ }^{6}$ According to the model presented in the previous section, real house prices would rise on average by around $3 \%$ over the medium term. The dynamics of the model implies that the price increase stimulates construction, which offsets part of the price increase in the long run. The strength of this stabilising mechanism hinges on the flexibility of the housing market. In a country with comparatively flexible land-use and rent-control regulations, real house prices come back to $0.4 \%$ above the baseline by 2050 . By contrast, 2050 real house prices will remain $1.4 \%$ above baseline in a country where rent control and land use are more rigid. ${ }^{7}$

6 . This $5 \%$ reduction in the primary-residence market could also be interpreted as modelling of a different kind of shock that has also received attention in recent years: speculative purchases by owners (foreign or domestic) who leave the property vacant.

7. Parameter values were taken from Ireland and Belgium, respectively, for these illustrative scenarios. 


\section{Box 2. The rise of home-sharing digital platforms: The case of Airbnb}

The rapid growth of home-sharing platforms like Airbnb raises questions about the potential impact on local communities as well as important policy challenges. On the positive side, home-sharing platforms like Airbnb create opportunities for the local economy: i) they provide a way to take advantage of under-utilised assets (e.g. housing stock that is neither owner-occupied nor available for long-term letting); ii) they offer an opportunity for owners to diversify their investment into short-term rentals and to earn extra income; iii) they foster tourism and expand consumers' options (OECD, 2019[26]).

On the negative side, in addition to the issues related to housing affordability, the rise in the popularity of Airbnb creates significant challenges such as i) unfair competition with the traditional accommodation sector; ii) potential negative externalities, like noise or congestion, created by the increased number of tourists; iii) potential issues of noncompliance with regulations, which could imply losses in tax revenues; iv) potential issues related to market concentration (Lee, 2016 $[27]$; OECD, 2019[26] $)$.

To provide a measure of the incidence of short-term Airbnb rentals in cities, this study builds two indicators using two data sources:

InsideAirbnb.com is an independent, non-commercial website, which reports data at monthly frequency on all Airbnb listings by city. It contains detailed information for 100 cities and regions in 30 countries between 2015 and 2019 on the characteristics of the listings, such as accommodation type (entire dwelling, private room or a shared room in an occupied flat), length of availability over a year expressed in number of days, price and reviews received by the host. It also contains the geographic coordinates of every dwelling listed on Airbnb. This data source does not allow assessing the impact of the COVID-19 crisis on demand for Airbnb accommodation, since it only covers supply.

The coordinates of listings are coupled with the GHSL geospatial dataset to calculate the population that lives in the area that is covered by the InsideAirbnb.com database for the city under consideration. In some cases (e.g. London), coverage nearly corresponds to the entire core functional urban area; in other cases (e.g. Paris), coverage is restricted to a narrower area (in this case the municipality of Paris). This approach ensures that the population corresponds to the area for which Airbnb listings are available.

The first indicator is the ratio between the proxy for the number of people that occupy an Airbnb accommodation of any type and the number of people living in the city. ${ }^{8}$ The values of this indicator for 36 cities are reported in Figure 11. Two main facts emerge. First, there is a considerable supply of Airbnb units in the cities of the sample. On average, the Airbnb population accounts for $3.2 \%$ of the city population, ranging from $0.4 \%$ in Istanbul to $13 \%$ in Copenhagen. Second, there has been a sharp increase in the supply of Airbnb listings during the past four years. Striking examples are Athens, Venice, Melbourne, Sydney and London, which recorded the strongest increase.

The second indicator is the ratio between the proxy for the number of people that occupy a long-term Airbnb accommodation (i.e. listed for more than 90 days per year) and the number of people living in the city (Figure 10). This is interpreted as a direct measure of occupants' displacement in regular rental and owner-occupier markets. For this

8 The proxy for the number of people living in an Airbnb accommodation is calculated assuming that on average an entire flat is inhabited by four people, a private room by two people and a shared room by one person. 
reason, it is used in the simulation exercise to evaluate the long-term impact of online matching platforms on house prices for short-term holiday rentals.

The time variation of this indicator reveals that cities that record a very high share of Airbnb occupants in units listed for more than 90 days in 2015, like Amsterdam, Copenhagen and Paris, show the biggest drop of this type of listings in 2019. These falls followed the introduction of regulations aimed at limiting the impact of short-term holiday rentals on local communities. A summary of the main changes in short-term rental regulation by country can be found in Appendix C. The information was extracted from the 2019 OECD Questionnaire on Affordable and Social Housing (QuASH).

Figure 11. Occupants of flats listed on Airbnb relative to city population

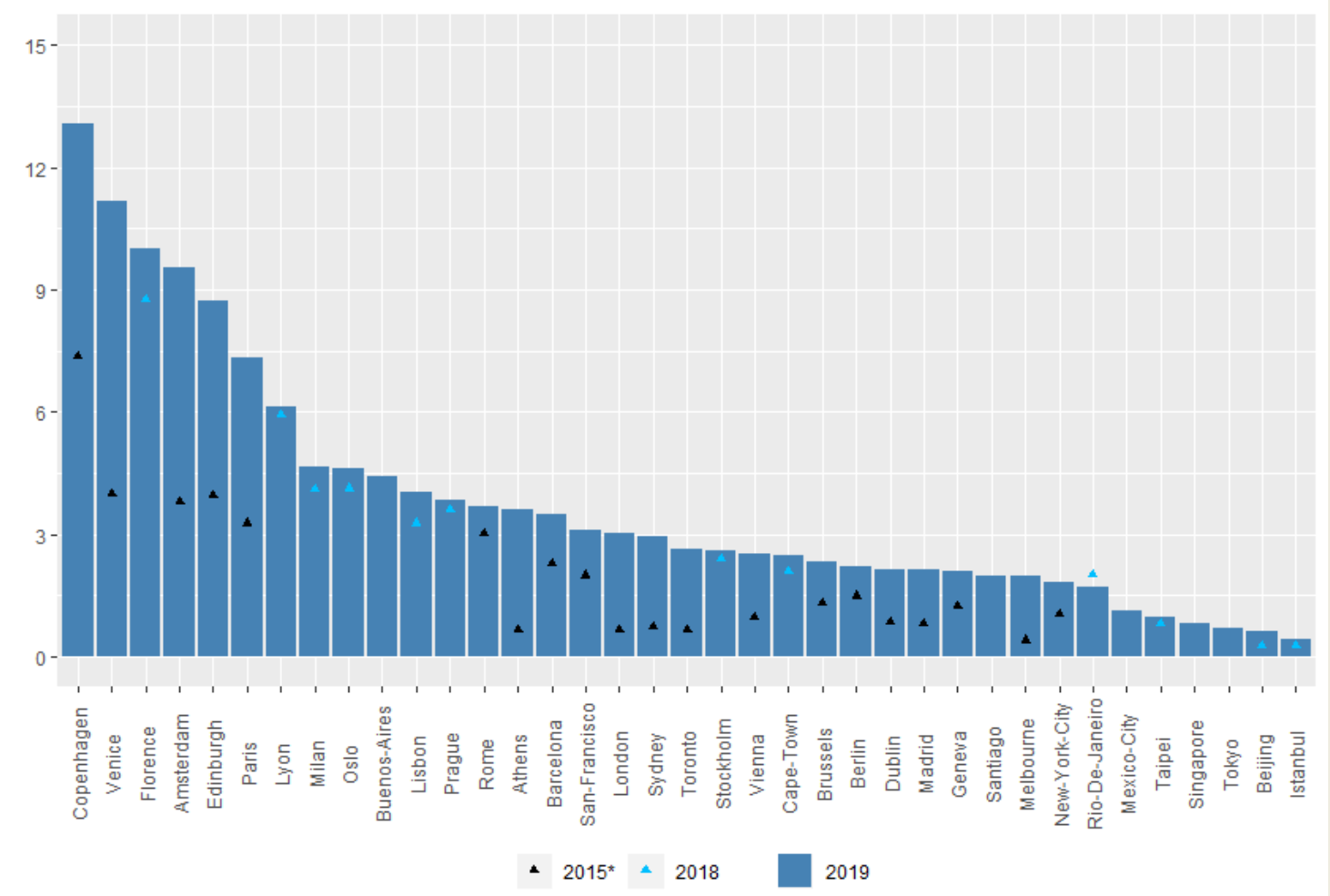

Note: The first available time value is 2016 for Copenhagen, Dublin and Geneva and 2017 for Rome. The proxy for the number of people living in an Airbnb accommodation is calculated assuming that on average an entire flat is inhabited by four persons, a private room by two persons and a shared room by one person.

Source: OECD calculation based on data from InsideAirbnb.com and GHSL. 


\section{References}

Ahlfeldt, G. and E. Pietrostefani (2019), "The Economic Effects of Density: A Synthesis", Journal of Urban Economics, Vol. 111, pp. 93-107, http://dx.doi.org/10.1016/j.jue.2019.04.006.

Ahrend, R., B. Cournède and R. Price (2008), "Monetary Policy, Market Excesses and Financial Turmoil", OECD Economics Department Working Papers, No. 597, OECD Publishing, Paris, https://dx.doi.org/10.1787/244200148201.

Alpanda, S. and S. Zubairy (2016), "Housing and Tax Policy", Journal of Money, Credit and Banking, Vol. 48/2-3, pp. 485-512, http://dx.doi.org/10.1111/jmcb.12307.

Barron, K., E. Kung and D. Proserpio (2018), The Sharing Economy and Housing Affordability, Association for Computing Machinery (ACM), http://dx.doi.org/10.1145/3219166.3219180.

Bétin, M. and V. Ziemann (2019), "How responsive are housing markets in the OECD? Regional level estimates", OECD Economics Department Working Papers, No. 1590, OECD Publishing, Paris, https://dx.doi.org/10.1787/1342258c-en.

Bricongne, J., A. Turrini and P. Pontuch (2019), "Assessing House Prices: Insights from "Houselev", a Dataset of Price Level Estimates", Discussion paper, No. 101, European Comission, http://dx.doi.org/10.2765/807.

Cavalleri, M., B. Cournède and E. Özsöğüt (2019), "How Responsive Are Housing Markets in the OECD? National Level Estimates”, OECD Economics Department Working Papers, No. 1589, OECD Publishing, Paris.

Cournède, B., S. Sakha and V. Ziemann (2019), "Empirical links between housing markets and economic resilience", OECD Economics Department Working Papers, No. 1562, OECD Publishing, Paris, https://dx.doi.org/10.1787/aa029083-en.

Diamond, R., T. McQuade and F. Qian (2019), "The effects of rent control expansion on tenants, landlords, and inequality: Evidence from san francisco", American Economic Review, Vol. 109/9, pp. 3365-3394, http://dx.doi.org/10.1257/aer.20181289.

DiPasquale, D. and W. Wheaton (1994), "Housing Market Dynamics and the Future of Housing Prices", Journal of Urban Economics, Vol. 35/1, pp. 1-27, http://dx.doi.org/10.1006/juec.1994.1001.

Engels, F. (1872/73), “Die Wohnungsfrage”, Der Volksstaat, Leipzig, http://www.mlwerke.de/me/me18/me18 209.htm.

Fischel, W. (2001), The Homevoter Hypothesis : How Home Values Influence Local Government Taxation, School Finance, and Land-Use Policies, Harvard University Press, https://books.google.fr/books?hl=fr\&lr=\&id=q9bJ6eZMR IC\&oi=fnd\&pg=PR9\&dq=homevoter thypothesis\&ots $=$ Y-DbzGiSg\&sig=YqYCANpWOUFnxtgNEXcRg9TRsM\#v=onepage\&q=homevoter hypothesis\&f=false.

Guillemette, Y. (2019), "Recent Improvements to the Public Finance Block of the OECD's LongTerm Global Model", OECD Economics Department Working Papers, No. 1581, OECD Publishing, Paris, https://dx.doi.org/10.1787/4f07fb8d-en. 
Guillemette, Y., A. De Mauro and D. Turner (2018), "Saving, Investment, Capital Stock and Current Account Projections in Long-Term Scenarios", OECD Economics Department Working Papers, No. 1461, OECD Publishing, Paris, https://dx.doi.org/10.1787/aa519fc9-en.

Guttentag, D. (2015), "Airbnb: Disruptive Innovation and the Rise of an Informal Tourism Accommodation Sector", Current Issues in Tourism, Vol. 18/12, pp. 1192-1217, http://dx.doi.org/10.1080/13683500.2013.827159.

Gyourko, J. and R. Molloy (2015), "Regulation and Housing Supply", Handbook of Regional and Urban Economics, Vol. 5, pp. 1289-1337, http://dx.doi.org/10.1016/B978-0-444-595317.00019-3.

Gyourko, J., A. Saiz and A. Summers (2008), "A New Measure of the Local Regulatory Environment for Housing Markets: The Wharton Residential Land Use Regulatory Index", Urban Studies, Vol. 45/3, pp. 693-729.

Hilber, C. and W. Vermeulen (2016), "The Impact of Supply Constraints on House Prices in England”, The Economic Journal, Vol. 126/591, pp. 358-405, http://dx.doi.org/10.1111/ecoj.12213.

Horn, K. and M. Merante (2017), "Is Home Sharing Driving up Rents? Evidence from Airbnb in Boston", Journal of Housing Economics, Vol. 38, pp. 14-24, http://dx.doi.org/10.1016/j.jhe.2017.08.002.

IEA (2019), Global Status Report for Buildings and Construction 2019 - Towards a ZeroEmissions, Efficient and Resilient Buildings and Construction Sector, IEA Publications, Paris, https://www.iea.org/reports/global-status-report-for-buildings-and-construction-2019.

IEA (2019), The Critical Role of Buildings - Perspectives for the Clean Energy Transition, IEA Publications, Paris, https://www.iea.org/reports/the-critical-role-of-buildings.

IEA (2017), Energy Technology Perspectives 2017, IEA Publications, Paris, https://www.iea.org/reports/energy-technology-perspectives-2017.

ITF (2019), ITF Transport Outlook 2019, OECD Publishing, Paris, https://dx.doi.org/10.1787/transp outlook-en-2019-en.

Johansson, Å. et al. (2013), "Long-Term Growth Scenarios", OECD Economics Department Working Papers, No. 1000, OECD Publishing, Paris, https://www.oecdilibrary.org/economics/long-term-growth-scenarios 5k4ddxpr2fmr-en.

Kamal-Chaoui, L. and A. Robert (2009), Competitive Cities and Climate Change, http://www.oecd.org/gov/regional/workingpapers.

Kholodilin, K. and S. Kohl (2020), "Does Social Policy through Rent Controls Inhibit New Construction? Some Answers from Long-Run Historical Evidence", Diskussionspapiere, No. 1839, http://www.diw.de/discussionpapers.

Knoll, K., M. Schularick and T. Steger (2017), "No Price Like Home: Global House Prices, 18702012", American Economic Review, Vol. 107/2, pp. 331-353, http://dx.doi.org/10.1257/aer.20150501. 
Larson, W. and W. Zhao (2020), "Self-driving cars and the city: Effects on sprawl, energy consumption, and housing affordability", Regional Science and Urban Economics, Vol. 81, http://dx.doi.org/10.1016/i.regsciurbeco.2019.103484.

Larson, W. and W. Zhao (2017), "Telework: urban form, energy consumption, and greenhouse gas implications", Economic Inquiry, Vol. 55/2, pp. 714-735, http://dx.doi.org/10.1111/ecin.12399.

Lee, D. (2016), How Airbnb Short-Term Rentals Exacerbate Los Angeles's Affordable Housing Crisis: Analysis and Policy Recommendations.

Miles, D. and J. Sefton (2017), "Houses Across Time and Across Place", CEPR Discussion Papers, No. 12103.

OECD (2020), Exploring the impact of shared mobility services on CO2, http://www.oecd.org/officialdocuments/publicdisplaydocumentpdf/?cote=ENV/EPOC/WPIEEP (2020)6/FINAL\&docLanguage=En.

OECD (2020), Housing Amid COVID-19: Policy Responses and Challenges, http://www.oecd.org/coronavirus/policy-responses/housing-amid-covid-19-policy-responsesand-challenges-cfdc08a8/.

OECD (2019), An Introduction to Online Platforms and Their Role in the Digital Transformation, OECD Publishing, Paris, https://dx.doi.org/10.1787/53e5f593-en.

OECD (2019), Enhancing the contribution of digitalisation to the smart cities of the future.

OECD (2019), Exploring the impact of shared mobility.

OECD (2019), OECD Economic Outlook, Volume 2019 Issue 2, OECD Publishing, Paris, https://dx.doi.org/10.1787/9b89401b-en.

OECD (2018), Taxation of Household Savings, OECD Tax Policy Studies, No. 25, OECD Publishing, Paris, https://dx.doi.org/10.1787/9789264289536-en.

OECD (2017), The Governance of Land Use, https://www.oecd.org/cfe/regionalpolicy/governance-of-land-use-policy-highlights.pdf.

OECD (2010), "Greener and Smarter: ICTs, the Environment and Climate Change", Vol. 2010/1, https://dx.doi.org/10.1787/5k9h3635kdbt-en.

OECD/ITF (2019), Benchmarking Accessibility in Cities - Measuring the Impact of Proximity and Transport Performance, https://www.itf-oecd.org/benchmarking-accessibility-cities (accessed on 12 February 2020).

Oszogut, E. (2020), Decentralisation and Governance in the Housing Sector: Analytic.

Pettit, C. et al. (2018), The Potential of New Technologies to Disrupt Housing Policy, Australian Housing and Urban Research Institute, http://dx.doi.org/10.18408/ahuri-7115001.

Phillips, L. (2020), "Decentralisation and inter-governmental relations in the housing sector", OECD Working Papers on Fiscal Federalism, No. 32, OECD Publishing, Paris, https://dx.doi.org/10.1787/2d3c3241-en. 
Saiz, A. (2010), "The Geographic Determinants of Housing Supply", Quarterly Journal of Economics, Vol. 125/3, pp. 1253-1296, http://dx.doi.org/10.1162/qjec.2010.125.3.1253.

Sommer, K. and P. Sullivan (2018), "Implications of US Tax Policy for House Prices, Rents, and Homeownership", American Economic Review, Vol. 108/2, pp. 241-274, http://dx.doi.org/10.1257/aer.20141751.

Wachsmuth, D. and A. Weisler (2018), "Airbnb and the Rent Gap: Gentrification Through the [25] Sharing Economy", Environment and Planning A, Vol. 50/6, pp. 1147-1170, http://dx.doi.org/10.1177/0308518X18778038. 
Appendix A. Data availability

\begin{tabular}{|c|c|c|c|c|c|c|}
\hline & Housing stock & House prices & Residential investment & Rent control & Land-use restrictiveness & Housing property taxation \\
\hline AUS & $x$ & $x$ & $\mathrm{X}$ & $\mathrm{X}$ & $\mathrm{X}$ & $\mathrm{X}$ \\
\hline AUT & $\mathrm{X}$ & $\mathrm{X}$ & $\mathrm{X}$ & $\mathrm{X}$ & $\mathrm{X}$ & $\mathrm{X}$ \\
\hline BEL & $\mathrm{X}$ & $\mathrm{X}$ & $\mathrm{X}$ & $\mathrm{X}$ & $\mathrm{X}$ & $\mathrm{X}$ \\
\hline BRA & $\mathrm{X}$ & $\mathrm{X}$ & & $\mathrm{X}$ & & \\
\hline CAN & $\mathrm{X}$ & $\mathrm{X}$ & $\mathrm{X}$ & $\mathrm{X}$ & $\mathrm{X}$ & $\mathrm{X}$ \\
\hline CHE & $X$ & $X$ & $X$ & $X$ & $X$ & $X$ \\
\hline CHL & 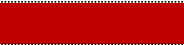 & $\mathrm{X}$ & $\mathrm{X}$ & $\mathrm{X}$ & $\mathrm{X}$ & $\mathrm{X}$ \\
\hline COL & 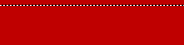 & $\mathrm{X}$ & $\mathrm{X}$ & $\mathrm{X}$ & $\mathrm{X}$ & \\
\hline CZE & $\mathrm{X}$ & $\mathrm{X}$ & $\mathrm{X}$ & $\mathrm{X}$ & $\mathrm{X}$ & $\mathrm{X}$ \\
\hline DEU & $\mathrm{X}$ & $\mathrm{X}$ & $\mathrm{X}$ & $\mathrm{X}$ & & $\mathrm{X}$ \\
\hline DNK & $\mathrm{X}$ & $\mathrm{X}$ & $\mathrm{X}$ & $\mathrm{X}$ & $\mathrm{X}$ & $\mathrm{X}$ \\
\hline ESP & $\mathrm{X}$ & $\mathrm{X}$ & $\mathrm{X}$ & $\mathrm{X}$ & $\mathrm{X}$ & $\mathrm{X}$ \\
\hline EST & $\mathrm{X}$ & $\mathrm{X}$ & $\mathrm{X}$ & $\mathrm{X}$ & $\mathrm{X}$ & $\mathrm{X}$ \\
\hline FIN & $\mathrm{X}$ & $\mathrm{X}$ & $\mathrm{X}$ & $\mathrm{X}$ & $\mathrm{X}$ & $X$ \\
\hline FRA & $\mathrm{X}$ & $\mathrm{X}$ & $\mathrm{X}$ & $\mathrm{X}$ & $X$ & $\mathrm{X}$ \\
\hline GBR & $X$ & $X$ & $X$ & $X$ & $X$ & $X$ \\
\hline GRC & $\mathrm{X}$ & $\mathrm{X}$ & $\mathrm{X}$ & & $\mathrm{X}$ & $\mathrm{X}$ \\
\hline HUN & $\mathrm{X}$ & $\mathrm{X}$ & $\mathrm{X}$ & & $\mathrm{X}$ & $\mathrm{X}$ \\
\hline IDN & & $\mathrm{X}$ & . & & 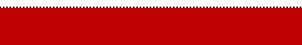 & 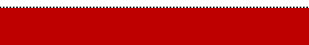 \\
\hline IND & & $\mathrm{X}$ & & & & \\
\hline IRL & $\mathrm{X}$ & $\mathrm{X}$ & $\mathrm{X}$ & $\mathrm{X}$ & $\mathrm{X}$ & $\mathrm{X}$ \\
\hline ISL & $\mathrm{X}$ & $\mathrm{X}$ & $\mathrm{X}$ & $\mathrm{X}$ & $\mathrm{X}$ & $\mathrm{X}$ \\
\hline ISR & & $\mathrm{X}$ & $\mathrm{X}$ & $X$ & $X$ & $X$ \\
\hline ITA & $\mathrm{X}$ & $X$ & $X$ & & $X$ & $X$ \\
\hline JPN & $X$ & $X$ & $X$ & & $X$ & $X$ \\
\hline KOR & & $X$ & $X$ & & $X$ & $X$ \\
\hline LTU & $X$ & $X$ & $X$ & & $X$ & \\
\hline LUX & $X$ & $X$ & $X$ & $X$ & $X$ & $X$ \\
\hline LVA & $X$ & $X$ & $X$ & $X$ & $x$ & $X$ \\
\hline MEX & & $X$ & $X$ & $X$ & & $X$ \\
\hline NLD & $X$ & $X$ & $X$ & $X$ & $X$ & $X$ \\
\hline NOR & $X$ & $X$ & $X$ & $X$ & $X$ & $X$ \\
\hline NZL & $X$ & $X$ & $X$ & $X$ & $X$ & $X$ \\
\hline POL & $X$ & $X$ & $X$ & $X$ & $X$ & $X$ \\
\hline PRT & $X$ & $X$ & $X$ & $X$ & $X$ & $X$ \\
\hline RUS & $X$ & $X$ & . & & 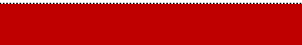 & \\
\hline SVK & $X$ & $X$ & $X$ & $x$ & $X$ & $X$ \\
\hline SVN & $X$ & $X$ & $X$ & & $X$ & $X$ \\
\hline SWE & $X$ & $X$ & $X$ & $X$ & $X$ & $X$ \\
\hline TUR & $X$ & $X$ & & & $X$ & $X$ \\
\hline USA & $X$ & $X$ & $X$ & $X$ & $X$ & $X$ \\
\hline ZAF & & $X$ & $X$ & & & $X$ \\
\hline
\end{tabular}


Appendix B. Policy scenarios: Housing stocks and price-to-income ratios

A. Dwelling stock (million units)

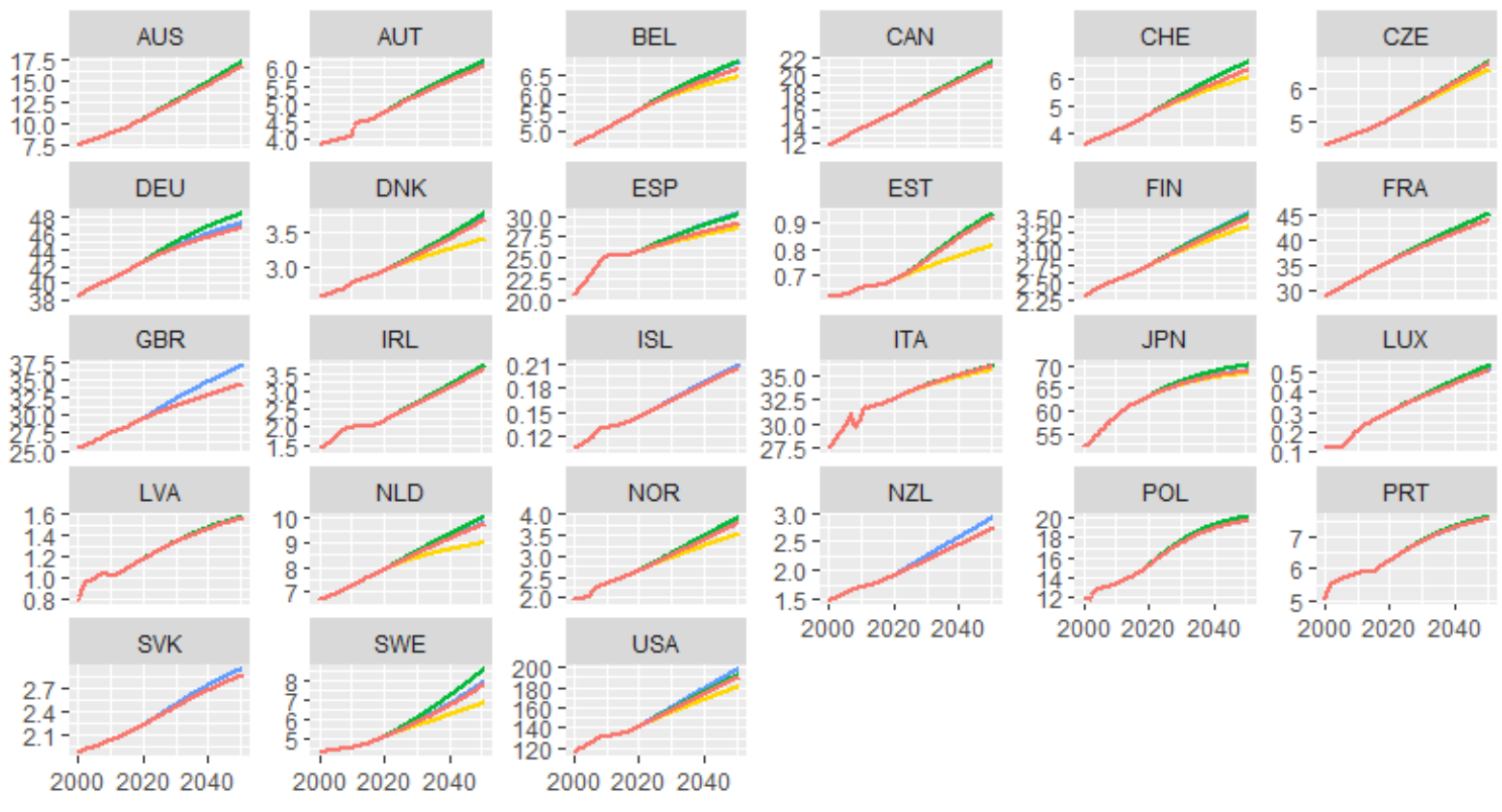

— Baseline — Deregulate rental markets — Streamline land-use policy — Remove mortgage interest relief

\section{B. Price-to-income ratio (no. of years to buy $100 \mathrm{~m} 2$ )}

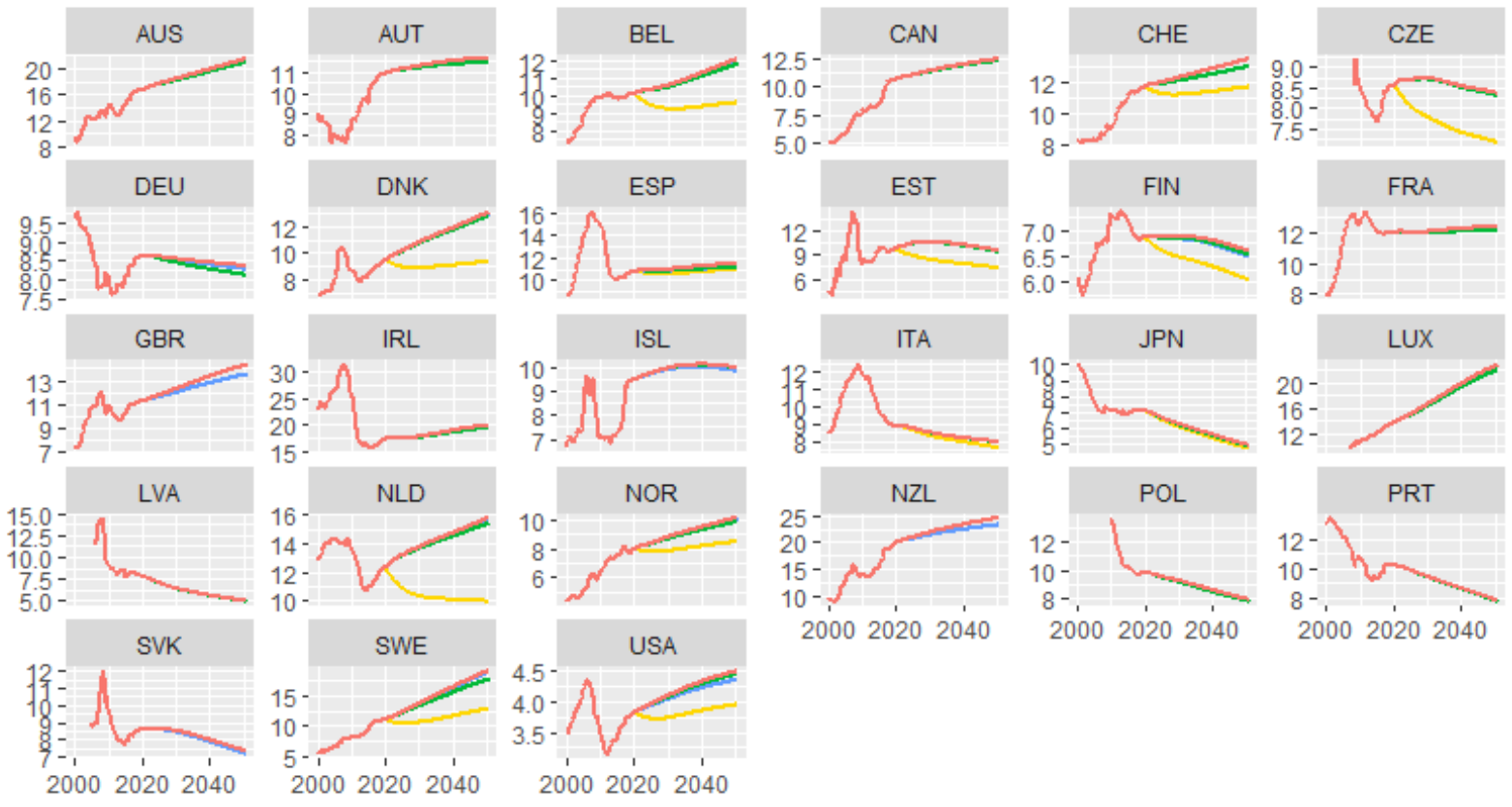

— Baseline - Deregulate rental markets — Streamline land-use policy — Remove mortgage interest relief

Note: Price-to-income ratios anchored at 2017 levels depicted in Figure 1. Note that price and income series differ between Bricongne, Turrini and Pontuch (2019[4] $)$ and the present model, which explains differences in price-to-income ratios in the year 2000. 


\section{Appendix C. Countries' regulation of long-term holiday rentals (e.g. Airbnb)}

\begin{tabular}{|c|c|c|c|c|}
\hline & \multicolumn{3}{|c|}{$\begin{array}{l}\text { Level(s) of government that has adopted, or } \\
\text { is considering adopting, measures targeting } \\
\text { long-term holiday rentals }\end{array}$} & \multirow[t]{2}{*}{ Description } \\
\hline & National/federal & Regional/state & Local/municipal & \\
\hline AUT & & $\mathrm{x}$ & $\mathrm{x}$ & $\begin{array}{l}\text { Prohibition of short-term touristic sub-letting in some regional development Acts, in } \\
\text { building regulations (e.g. Vienna), or in subsidy regulations (exclusion of sub-letting). }\end{array}$ \\
\hline CAN & & & $\mathrm{X}$ & $\begin{array}{l}\text { Vancouver, Toronto, and other large cities are considering adopting measures to limit } \\
\text { short-term holiday rentals. }\end{array}$ \\
\hline CZE & $\mathrm{X}$ & & $\mathrm{X}$ & The country is considering taxes on short-term rentals \\
\hline DNK & $\mathrm{X}$ & & $\mathrm{X}$ & $\begin{array}{l}\text { National/federal level: the Danish Parliament has adopted a bill that contains annual } \\
\text { limits for the rental of one's own full permanent residence. Up until January } 1 \text { st } 2021 \\
\text { the limit is } 70 \text { days of rental (the municipality can decide to raise the limit up until } 100 \\
\text { days). After January } 1 \text { st, } 2021 \text { the limit is } 30 \text { days if the owner/user provides the rental, } \\
70 \text { days if an agency provides for the rental. Local municipal level: the municipality can } \\
\text { raise the } 70 \text { days limit up until } 100 \text { days. }\end{array}$ \\
\hline FRA & $\mathrm{X}$ & & & $\begin{array}{l}\text { Starting January } 1,2019 \text { entire primary residences listings are allowed to host } \\
\text { reservations for a maximum of } 120 \text { nights per calendar year (from 1st January to } 31 \text { st } \\
\text { December). }\end{array}$ \\
\hline ISL & $\mathrm{x}$ & & & $\begin{array}{l}\text { The number of days rented out shall not exceed } 90 \text { days in aggregate per calendar year } \\
\text { for each individual, nor shall the combined income from the lease of the assets exceed } \\
\text { the amount of } 2,000,000 \mathrm{kr} \text {. }\end{array}$ \\
\hline ISR & & & $\mathrm{x}$ & $\begin{array}{l}\text { The City of Tel-Aviv has requested doubling the property tax for Airbnb apartments. The } \\
\text { request needs the approval of the Minister of Finance and the Minister of the interior. }\end{array}$ \\
\hline MEX & $\mathrm{X}$ & & & $\begin{array}{l}\text { The Income Tax and Value Added Tax Laws establish that the host incomes for short- } \\
\text { term / holiday rentals are subject to tax payment. }\end{array}$ \\
\hline NLD & & & $\mathrm{X}$ & $\begin{array}{l}\text { In Amsterdam owners may only offer their dwellings for a limited number of days per } \\
\text { year }(60) \text { for short-term rental purposes and dwellings offered for short-term rental must } \\
\text { be registered with the municipality }\end{array}$ \\
\hline NOR & $\mathrm{X}$ & & & The country introduced a ban on short-term rental for more than 90 days a year. \\
\hline POL & $x$ & & & $\begin{array}{l}\text { A new act is planned which will introduce provisions for dwellings rented during a stay } \\
\text { of up to } 30 \text { days. }\end{array}$ \\
\hline GBR & $x$ & & & $\begin{array}{l}\text { Landlords who let property on a short-term basis must rent out accommodation } \\
\text { responsibly and in accordance with the law. Local authorities already have powers to } \\
\text { enforce breaches of planning control and to take action against statutory nuisance. The } \\
\text { Government is encouraging industry to build on this by working proactively with local } \\
\text { authorities to stamp out bad practice. }\end{array}$ \\
\hline USA & & & $x$ & $\begin{array}{l}\text { In New Orleans there is prohibition of short-term rentals in the French Quarter, taxation } \\
\text { of bookings executed through Airbnb. Los Angeles has similar restrictions. }\end{array}$ \\
\hline $\mathrm{COL}$ & $x$ & & & $\begin{array}{l}\text { Since the tax reform of } 2016 \text { service providers that are not resident in Colombia must } \\
\text { register with the Colombian tax administration (DIAN) and declare and pay taxes every } \\
\text { two months. }\end{array}$ \\
\hline IRL & $x$ & & & $\begin{array}{l}\text { Unrestricted home-sharing and limited short-term letting are capped at } 90 \text { days per } \\
\text { year. }\end{array}$ \\
\hline CRI & $x$ & & & $\begin{array}{l}\text { A law regulates the rights of users as well as the obligations of service providers, } \\
\text { creates a registry of non-traditional lodging companies, establishes operating } \\
\text { requirements for tourist services of non-traditional lodging companies; establishes a tax } \\
\text { on all non-traditional lodging companies. }\end{array}$ \\
\hline NZL & & $X$ & & $\begin{array}{l}\text { The Queenstown Lakes District Council has introduced a new system designed to } \\
\text { ensure that owners of residential properties that are used by paying guests pay } \\
\text { additional rates as they create more pressure on infrastructure. The Auckland council } \\
\text { has introduced a "targeted accommodation rate" for the same purpose. }\end{array}$ \\
\hline DEU & & & $x$ & $\begin{array}{l}\text { In big cities and touristic hotspots (Berlin, Hamburg, Munich, Frankfurt/Main, } \\
\text { Nuremberg) using living space for other than residential purposes has to be indicated; } \\
\text { it has to be approved by the local government. In } 2019 \text {, Berlin introduced the prohibition } \\
\text { of use for other purposes. }\end{array}$ \\
\hline
\end{tabular}

Source: 2019 OECD Questionnaire on Affordable and Social Housing (QuASH). 


\section{Annex A: Housing, urban mobility and the environment - A tale of multidimensionality}

The provision of efficient, sustainable and inclusive housing is crucial for the well-being of citizens. Housing involves many different drivers of people's well-being including affordability, environmental quality and the liveability of cities (Figure A.1). This annex draws on long-term scenarios by the International Transport Forum, the International Energy Agency and the simulation framework outlined in the main text to assess how two key future developments, the renewal of urban mobility and efforts to curb climate change, are likely to affect housing markets, including future prices. It thereby highlights the complementarities and trade-offs that arise when tackling these challenges surrounding the future of housing.

Figure A.1. The future of housing can be sustainable, inclusive and efficient

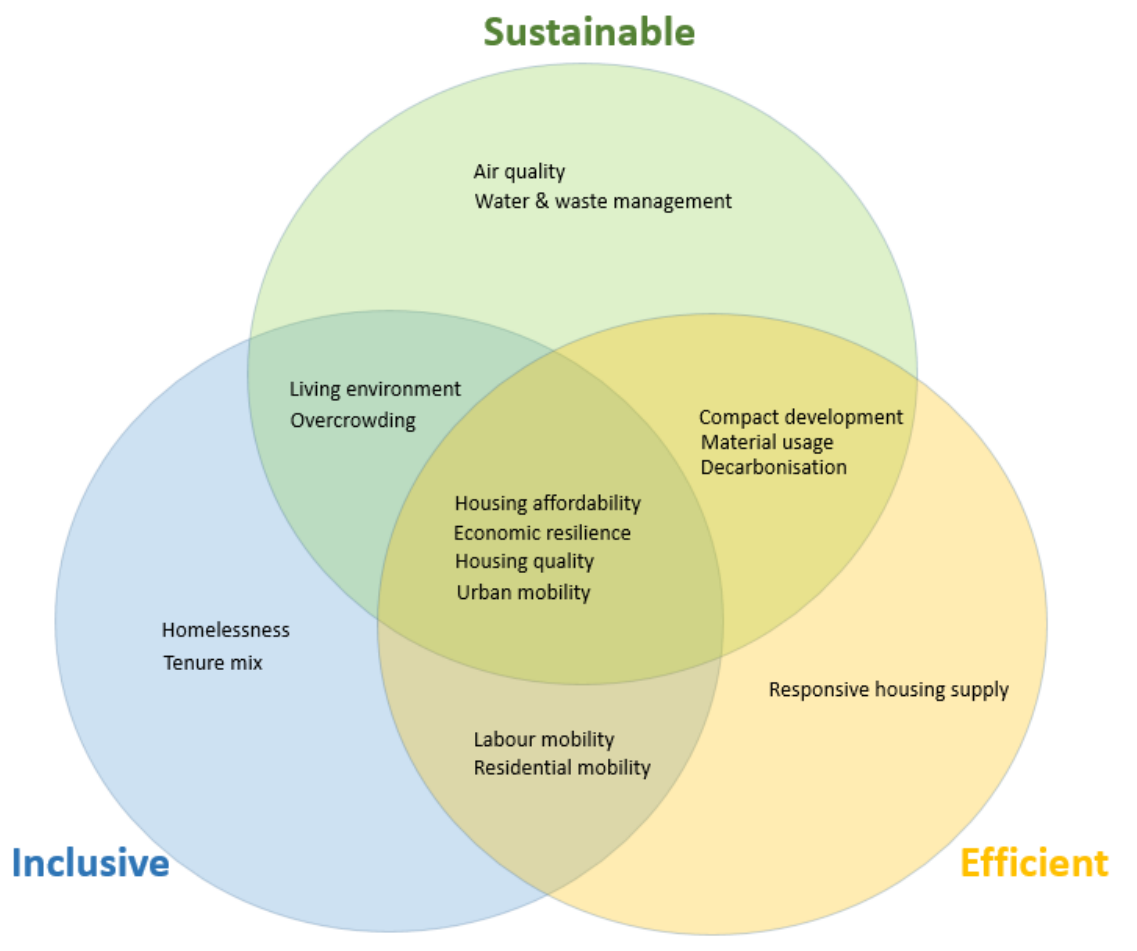

\section{Greening urban mobility}

Changes in urban mobility usually have deep implications for house prices. The past decades have been characterised by increasing congestion, but new technologies facilitating car sharing, which could culminate with the advent of the sharing of automated electric or hydrogen-powered cars, may bring about a turnaround. 


\section{Urban mobility 4.0}

The technological transformation of urban mobility through as real-time public transit information, digital public transit payment, intelligent traffic signals, car and bike sharing, smart parking and autonomous vehicles have the potential to significantly improve transport efficiency (OECD, 2010[28]; OECD, 2019[29]). The rise of teleworking is also transforming the need for mobility. These trends are key ingredients of the move towards smart cities. ${ }^{9}$ Better transport efficiency can enhance wellbeing in several ways:

- By reducing commuting costs, it favours the organic growth of cities, with positive consequences for housing affordability;

- By facilitating access to jobs and services to citizens living in areas with lack of such services, it can boost inclusiveness;

- By reducing passengers transport emissions, it benefits the environment. ${ }^{10}$

An empirical consensus is emerging that new forms of urban mobility underpinned by digital technologies can contribute to improve housing affordability. For example, a recent study by Larson and Zhao (2020[30] shows that the adoption of autonomous vehicles makes housing more affordable by increasing the effective supply of land in cities. Specifically, falling transportation costs make the land outside the city more usable, encouraging the growth of cities, but it also frees up land within the city due to less demand for parking space. Higher land availability relaxes the pressure on house prices, especially in cities where land-use policy is less restrictive. Similarly, the opportunity of teleworking replaces the need for physical commuting, while also lowering the demand for parking space. This increases the availability of land and, in cities with less restrictive land-use regulation, is associated to a reduction in house prices (Kamal-Chaoui and Robert, 2009 $9_{[31]}$; Larson and Zhao, 2017[32]). A recent OECD study found that shared mobility eases pressure on house prices (OECD, 2019[33]).

The advent of shared mobility on a large scale could change travel patterns in cities and significantly improve accessibility. Digital technology offers a very effective way to match demand for travel and supply of rides, so that shared travel becomes compatible flexibility. The shared alternatives include on-demand door-to-door rides by shared taxis and pre-booked transfer-free rides at pop-up stops by taxi buses. The induced shorter vehicle lifetimes lead to a more frequent fleet renewal, which enables a quicker fleet turnover and a faster penetration of fuel-efficient or alternative fuel technologies. In addition, trips would be cheaper, due to a more efficient use of capacity. Considerably eased congestion would raise travel speeds and potentially shift housing demand away from central business districts or transport corridors; this reduced concentration of demand would make housing more affordable by reducing core urban land prices.

The latest ITF $\left(2019_{[34]}\right)$ projections foresee an increase in shared mobility from only $1 \%$ in 2015 to above $20 \%$ by 2050 on current policy plans and $36 \%$ in a more ambitious scenario (Figure A.2). Another recent OECD study suggests that shared mobility could expand to above $40 \%$ by 2035 and nearly $50 \%$ by 2050 , if all obstacles to its take-up are removed (OECD, 2020[35]).

9. The OECD defines smart cities as "initiatives or approaches that effectively leverage digitalisation to boost citizen well-being and deliver more efficient, sustainable and inclusive urban services and environments as part of a

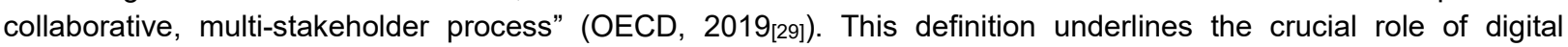
innovation for the smart city concept, while also highlighting its contribution to improve well-being.

10. A recent study by the OECD shows that shared mobility services can eliminate, on average, $6.3 \%$ of passengers transport emissions (OECD, 2019 ${ }_{[33]}$ ), in cities where public transport is less popular. However, the combined effects of further urbanisation and income growth can also result in a surge in emissions (Larson and Zhao, 2020[30]). 
Figure A.2. Urban mobility is projected to expand over 2015-50

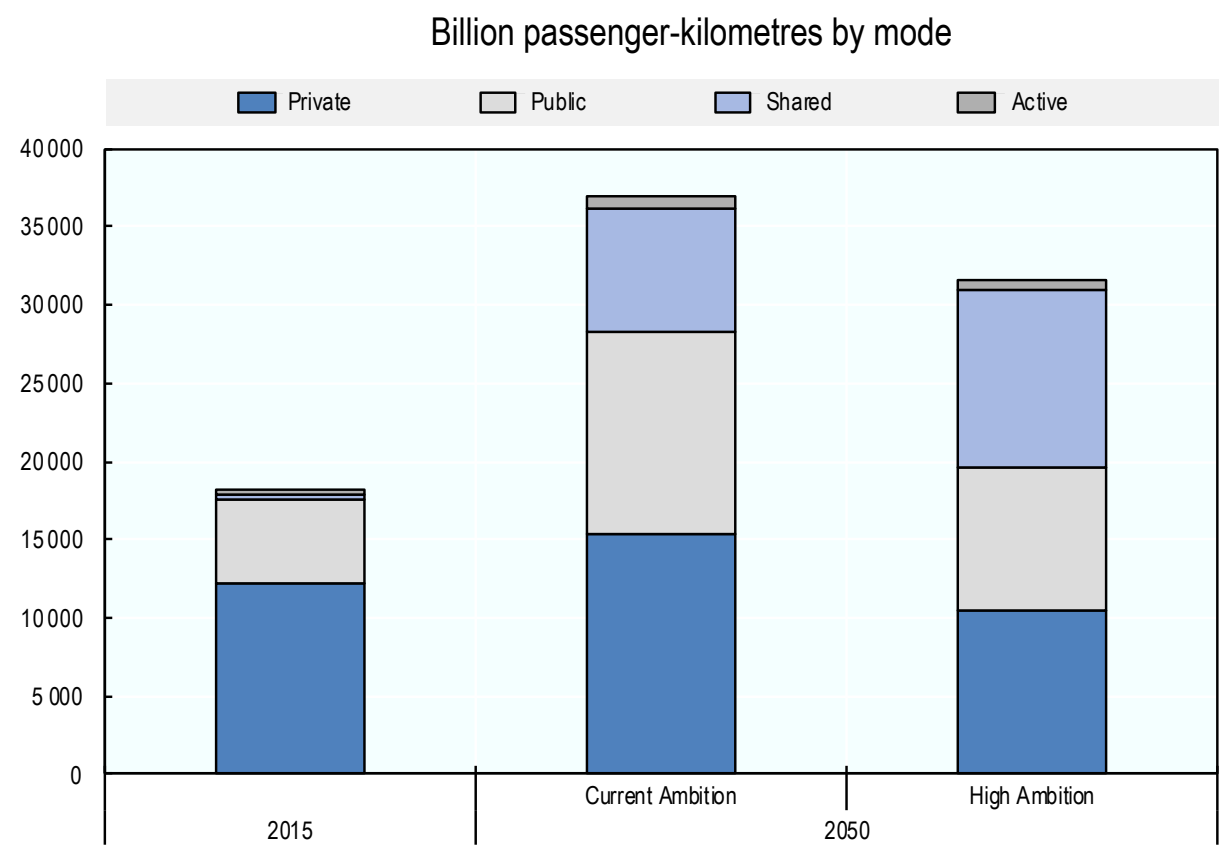

Note: Private refers to private motorised vehicles or taxis. Public refers to bus, metro, tram, and rail; Shared refers to motorised and nonmotorised shared vehicles, including shared vehicle systems (i.e. free-floating or non-free-floating shared cars, bikes or other) and optimised shared mobility services (i.e. shared taxis, vans or minibuses with a driver); Active comprises travel undertaken by foot, bicycle, or other humanpowered mode (where a vehicle is not publically shared).

Source: ITF Transport Outlook 2019 (ITF, 2019[34]).

\section{Shared urban mobility reduces congestion and eases house price growth}

Real house prices have roughly followed construction costs in the first half of the $20^{\text {th }}$ century but been rising much faster than them virtually everywhere since the 1950s. In many countries, the divergence from construction costs has been steep in recent decades. Miles and Sefton $\left(2017_{[36]}\right)$ have calibrated a model that tracks the long-term development of house prices well. An important driver is the cost of travelling, in terms of a bus or rail fare or fuel tank refill. Travel cost also includes the time it takes to get to work or shops. The development of rail in the second part of the nineteenth century and underground urban networks in the first half of the twentieth century brought travel costs down; dramatically increased car use then brought cost further down. These very strong improvements in urban transport through the first half of the $20^{\text {th }}$ century resulted in broadly stable real house prices despite the sharp rise in urban population and income (Knoll, Schularick and Steger, 2017[6]; Miles and Sefton, 2017[36]). The reason is that these urban-transport improvement allowed an increase in the average commuting distance and thus increased the available quantity of land within a given commuting time of large urban centres, which has improved affordability considerably all other things equal.

More recently, however, the improvement in travel speeds has slowed or has even reversed due to congestion, which acts as a push-factor on house prices. Growing populations, rising income and urbanisation combined with the rising density of cities were the other major drivers of fast rising house prices over the last 70 years (Knoll, Schularick and Steger, 2017[6]). However, the digitally enabled rise in vehicle sharing could transform urban mobility, with the potential of reducing emissions and reversing the trend rise in congestion, which could in turn restrain housing price increases. 
Lower travel speeds have implied less sprawling and a higher density of cities. Betin and Ziemann (2019 $\left.{ }_{[2]}\right)$ have estimated house price equations using a regional data set for 12 OECD countries. They include population and construction costs, obstacles to construction, such as inland water as well as the share of high-density areas as drivers of house prices. The elasticity of house prices with respect to the share of high-density areas is 0.5 , which implies that, when the share of high-density areas increases by 10 per cent, house prices increase by 5 per cent. A meta-analysis by Ahlfeldt and Pietrostefani $\left(2019_{[37]}\right)$ suggests a density elasticity of house prices with respect to density of 0.15 , but the elasticity increases with density. A population density increase of 1000 inhabitants per square kilometre raises this elasticity by 0.06 .

A recent study has assessed the performance of various modes of transport across 121 European functional urban areas (FUA) by comparing proximity and actual accessibility of schools, restaurants, shops and other destinations within 15,30 or 45 minutes (OECD/ITF, 2019 $9_{[38]}$ ). The proximity indicator yields the number of destinations that lie within a radius of $4 \mathrm{~km}$ (15 min), $8 \mathrm{~km}$ (30 min) or $12 \mathrm{~km}$ (45 min). Actual accessibility by car takes into account the road infrastructure, legal speed limits, intersections, average congestion coefficients and average observed travel speeds. From a housing market perspective, restaurants serve as a suitable proxy for economic and cultural activity that citizens typically wish to reach in due time. Accordingly, for each cell within the FUA, a car performance index measures the share of restaurants that can effectively been reached by car in 15 minutes relative to the number of restaurants that lie within a radius of $4 \mathrm{~km}$. The FUA aggregate is obtained by a population-weighted average across all cells. For each country covered by the study, Figure A.3 shows the median FUA's car performance index.

\section{Figure A.3. Urban mobility performance by car varies considerably across OECD countries}

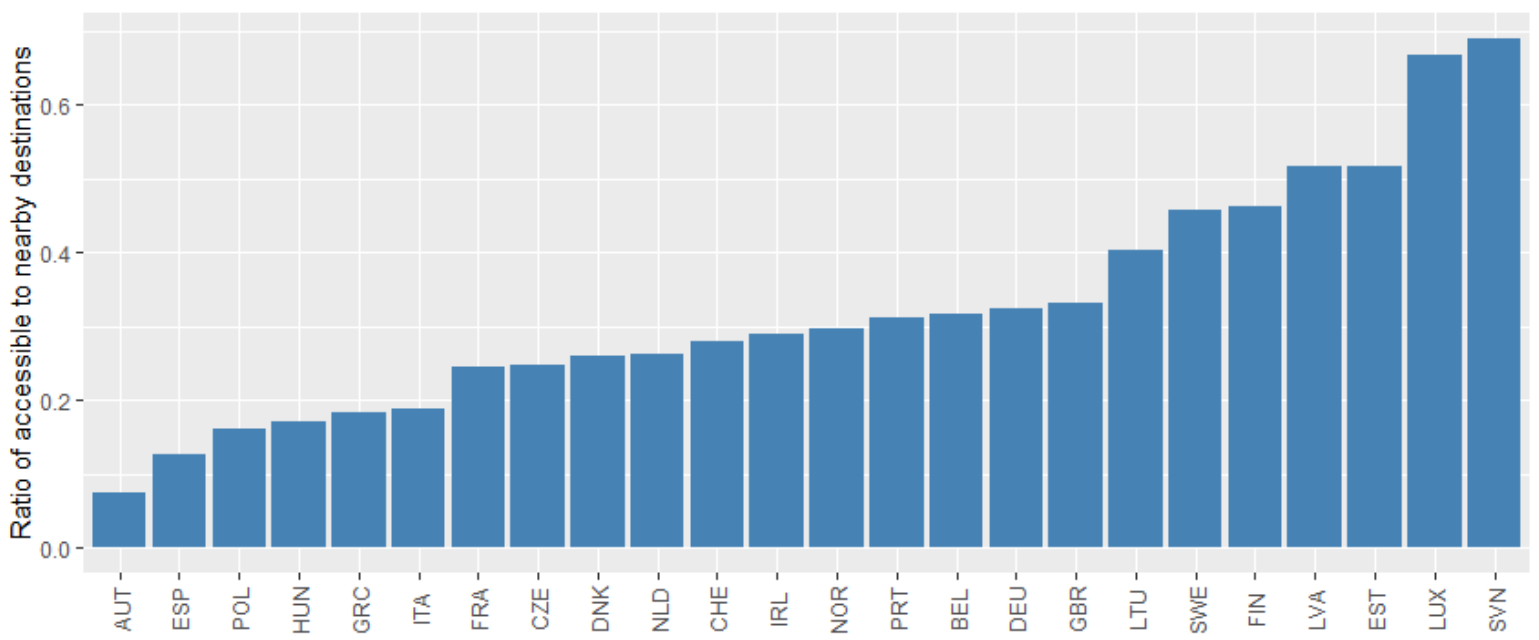

Note: The car performance index measure the average share of restaurants that can effectively been reached by car in 15 minutes compared to the number of restaurants that lie in a radius of $4 \mathrm{~km}$. Medians by country a shown.

Source: Benchmarking Accessibility in Cities - Measuring the Impact of Proximity and Transport Performance (OECD/ITF, 2019[38]).

The empirical framework described in the main text allows assessing the impact of urban mobility performance on house prices. A greater ease of driving to centres of economic and cultural activity, proxied by the number of restaurants is found to ease pressures on house prices Table A.1. The car performance index also reflects the quality of public transport and other mobility options (such as biking), since increased use of alternatives to cars will have the side-effect of reducing congestion. The estimated coefficient of the interaction with disposable income suggests that an improvement in urban mobility, for instance through a 
reduction of road congestion, by 10 percentage points reduces house prices by around 5 per cent in the average country.

Table A.1. Urban mobility performance influences house prices

Dependent variable: Real house prices

\begin{tabular}{l|c|c|c|c}
\hline \multicolumn{1}{c|}{ Variable } & Coefficient & Std. Error & t-Statistic & Prob. \\
\hline Log real per capita disposable income & 1.684 & 0.054 & 31.253 & 0.000 \\
\hline Real interest rate & -0.687 & 0.133 & -5.148 & 0.000 \\
\hline Log dwelling stock (housing units) & -0.693 & 0.075 & -9.224 & 0.000 \\
\hline Log disposable income $x$ tax rate on housing & -1.156 & 0.082 & -14.092 & 0.000 \\
\hline Log disposable income x car performance index & -1.365 & 0.249 & -5.488 & 0.000 \\
\hline Log population & 1.320 & 0.170 & 7.771 & 0.000 \\
\hline Periods included: & 148 & Adjusted R-squared: & 0.767 \\
\hline Cross-sections included: & 20 & Country-fixed effects: & Yes \\
\hline Total panel observations: & 2102 & Time-fixed effects: & No \\
\hline
\end{tabular}

Note: The panel runs from 1981Q1 to 2017Q4 and includes 20 countries. The dwelling stock is lagged by 1 year.

Source: OECD calculations.

Using these estimates, the right panel of Figure A.4 depicts by how much house-price-to-income ratios are simulated to decline on the assumption that car sharing improves urban mobility so that half of the nearby restaurants can be reached in 15 minutes (red line on the left panel). The biggest impact of such an improvement would occur in Ireland and Austria, where the price of an average $100 \mathrm{~m}^{2} \mathrm{dwelling}$ would decline by 3 years of disposable income below the level that it would reach on unchanged urban mobility.

\section{Figure A.4. Reducing congestion could boost housing affordability}
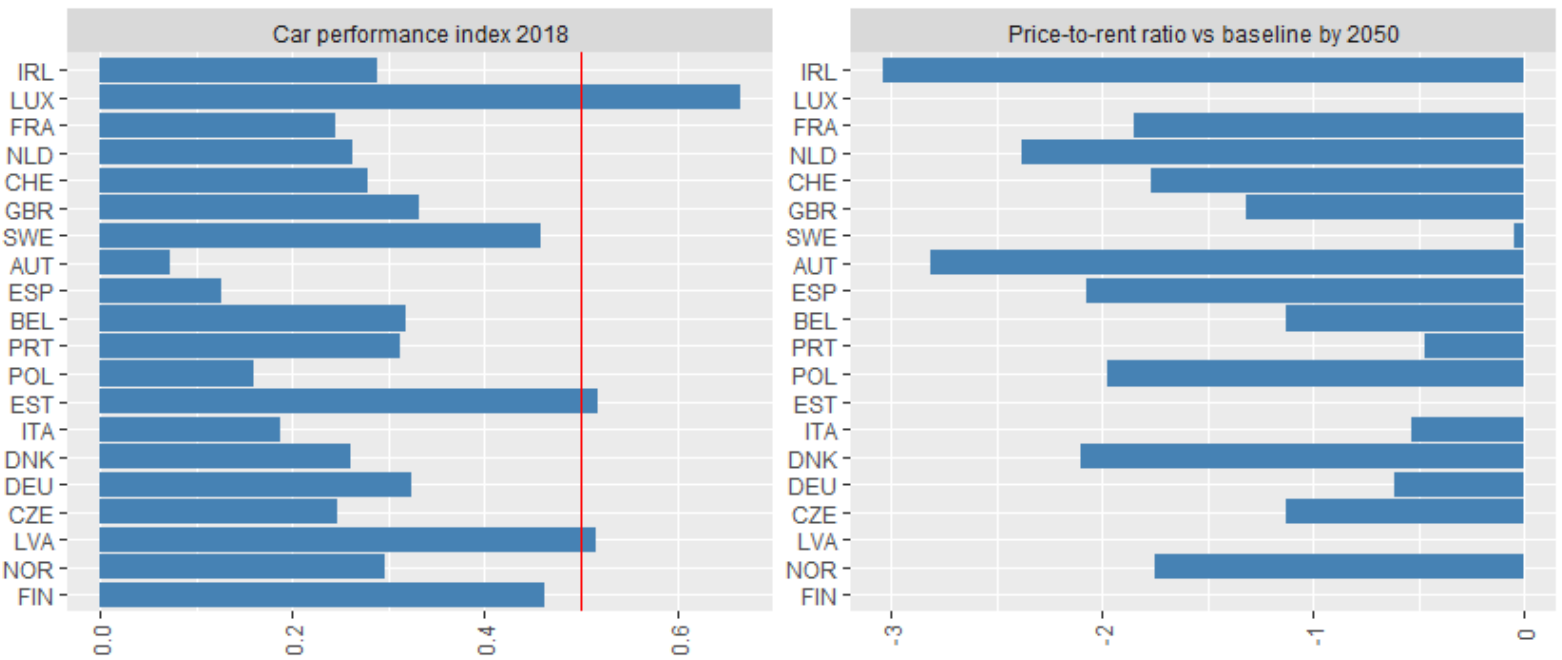

Note: Left panel depicts the ratio of theoretical to actual number of restaurants that citizens can reach within 15 minutes by car (OECD/ITF, $2019_{[38]}$ ). The red line indicates the target assumed to be reached gradually over the projection horizon (one $20^{\text {th }}$ of the difference to target per quarter). The right panel shows the simulated impact on price-to-income ratios in years of disposable income required to purchase a $100 \mathrm{~m}^{2}$ dwelling.

Source: "Benchmarking Accessibility in Cities - Measuring the Impact of Proximity and Transport Performance" (OECD/ITF, 2019[38]) and OECD calculations. 


\section{The environmental consequences of changes in urban mobility}

The renewal of urban mobility brought about by car sharing overall is expected to result in lower polluting emissions. The greater efficiency in the use of cars (fewer cars per passenger-km travelled) should in most cities dominate the opposite effects: more travel and some substitution away from public transport (OECD, $2020[35])$. Other forces, such as tightening emission standards, the emergence of electric cars and policies to promote other transport modes, are also shaping the future of urban mobility.

The International Transport Forum has developed long-term scenarios for the future of mobility within cities taking account of these forces. They are based on a model that was developed to evaluate the impacts of transport, environment and technology substitution policies through projections of travel demand, $\mathrm{CO}_{2}$ emissions and accessibility for all cities in the world with more than 50000 inhabitants until 2050.

In the current ambition scenario, no additional measures are taken beyond already announced policies set to take effect in the future. This scenario provides a baseline for travel demand and $\mathrm{CO}_{2}$ emissions in the urban transport sector against which alternative policy scenarios can be compared. It assumes that the future trends of car ownership, road supply, public transport supply, pricing structure and urban area growth will follow the trajectories of the past. The baseline scenario suggests that mobility as measured by passenger-kilometres would roughly double until 2050 (Figure A.2). Emissions nevertheless fall by $20 \%$ in 2050 compared with 2015 thanks to better use of vehicles, through increased sharing, and the large expected fuel efficiency gains (Figure A.5).

\section{Figure A.5. Urban passenger transport $\mathrm{CO}_{2}$ emissions are projected to abate over 2015-50 Million tonnes}

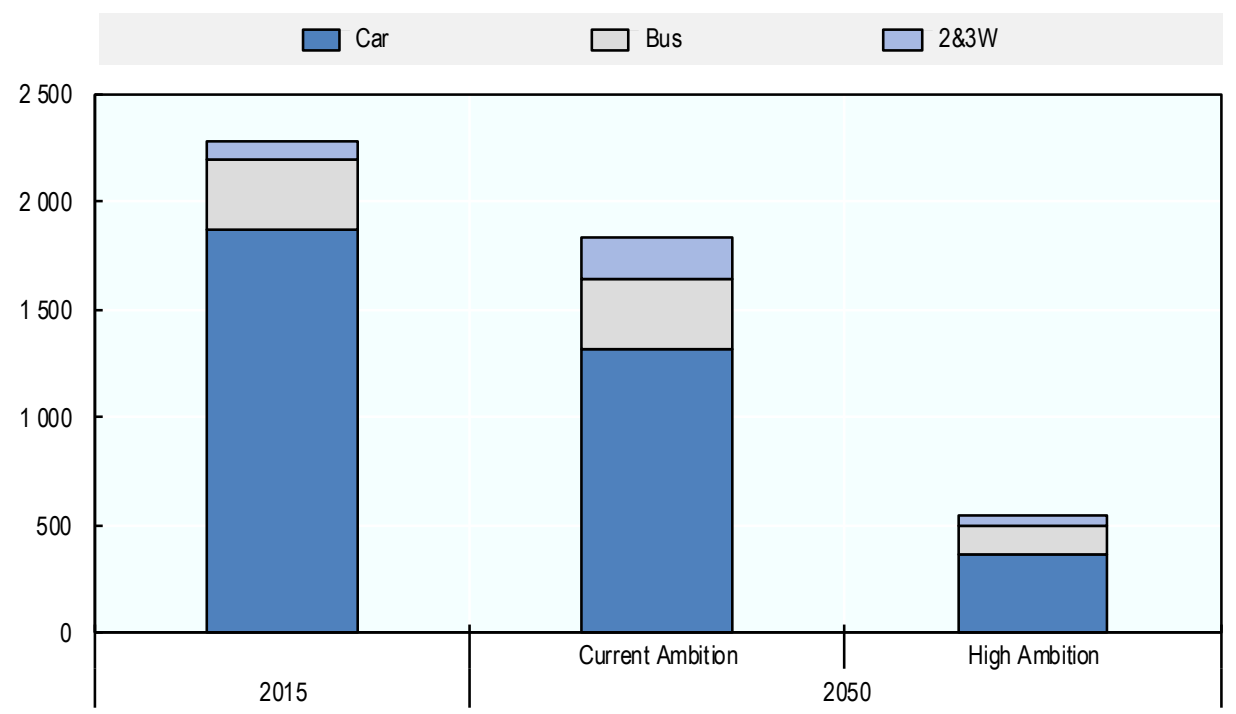

Source: ITF Transport Outlook 2019 (ITF, 2019[34]).

The High Ambition scenario assumes that governments implement policies to optimise the use of public space and reduce negative externalities from urban transport. Funding for public transport rises, while integrated policies for land use and transport result in higher urban density. The uptake of electric vehicles accelerates. While parking prices are $50 \%$ higher than in the baseline, better integration of public transport modes also allows a higher share of public and active (walking and biking) transport modes. Teleworking is encouraged, which reduces urban travel demand. Better public transport options combined with more 
compact urban development directly contribute to increased public transport use and decreased trip distance. In this ambitious policy-reform scenario, $\mathrm{CO}_{2}$ emissions from the urban transport sector would be divided by more than four in 2050 compared with 2015 .

\section{Decarbonising housing ${ }^{11}$}

\section{The challenge}

The residential buildings sector accounted for $22 \%$ of global final energy consumption in 2018 (Figure A.6). Direct $\mathrm{CO}_{2}$ emissions, those related to building homes, accounted for $6 \%$ of total global energy-related $\mathrm{CO}_{2}$ emissions. Yet, buildings consume more than $55 \%$ of global electricity use (IEA, $\left.2019_{[39]}\right)$. When these indirect emissions are taken into account, the total carbon footprint of the residential buildings sector rises to $17 \%$. Over time, global emissions from buildings have trended up until 2018 . Floor space increases were the major driver. They were not fully offset by the trend decline in the energy intensity (energy use per square meter) of building and using homes.

Figure A.6. Housing accounts for $22 \%$ of final energy use and $17 \%$ of energy-related $\mathrm{CO}_{2}$ emissions

\section{8}
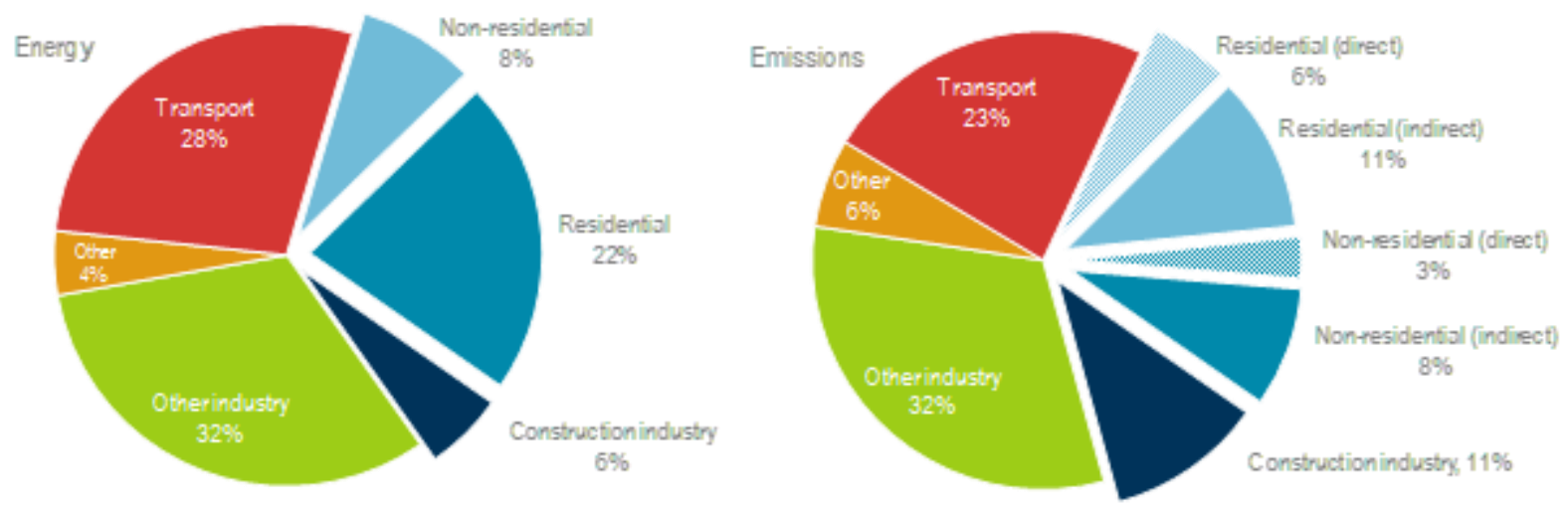

Source: IEA (2019[40]), Global Status Report for Buildings and Construction 2019: Towards a Zero-emissions, Efficient and Resilient Buildings and Construction Sector, IEA Publications.

Energy efficiency improvements combined with a change in the heating fuel mix has curbed direct emissions by $10 \%$ over the past 10 years, despite floor area and energy demand growth. But further efforts are needed to put the residential buildings sector on a trajectory complying with the Paris agreement. The IEA produces a new policies scenario out to 2050 (IEA, 2017[41]), Box A.1). This scenario provides insights on the future effects of today's policy ambitions. The new policies scenario assumes the materialisation of some promising trends. For example, global energy demand growth is about half as large as it would be if current and announced energy efficiency policies were excluded from the projection. The new policies scenario also assumes substantial growth in renewables, with renewables-based power generation more than tripling from today's level by 2050 and the average $\mathrm{CO}_{2}$ intensity of power generation being cut in half by 2050 . Despite these attenuating factors, the global emissions trajectory in the New Policies Scenario is

\footnotetext{
${ }^{11}$ This section draws mainly on IEA (2019[39]) and an online annex outlining the IEA's Energy Technology Perspectives model.
} 
still far from what is required to achieve the objectives of the Paris Agreement. Energy-related $\mathrm{CO}_{2}$ emissions under the New Policies Scenario continue to rise until 2050, gradually increasing from around $32.6 \mathrm{GtCO} 2$ today to over $36 \mathrm{GtCO} 2$ by 2050.

\section{Box A.1. The IEA Energy Technology Perspectives Model}

The IEA scenarios are built with the IEA Energy Technology Perspectives (ETP) model and the IEA World Energy Model. The ETP model provides technology-rich scenarios, interlinking four sectoral models focused on buildings, industry, transport and power. The buildings model is framed as a simulation stock accounting that disaggregates the residential and non-residential (i.e. commercial and public) sub-sectors for 35 world regions. This is used to analyse the impacts of policy measures such as energy efficiency regulations, technology choices and their evolution over time under various scenarios such as the New Policies Scenario and the Faster Transition Scenario (see: www.iea.org/etp.)

The model uses historical and socio-economic data as inputs (Figure A.3). It derives final energy demand from energy demand drivers, such as residential floor area projections and technology data to produce detailed energy use projections for the building envelope, space heating and cooling, water heating, cooking, lighting and appliances. Final energy outputs are converted into $\mathrm{CO} 2$ emissions using power sector intensity signals.

Figure A.7. The IEA ETP model projects energy demand and emissions

INPUT

\begin{tabular}{|c|c|}
\hline $\begin{array}{c}\text { Historical } \\
\text { data }\end{array}$ & $\begin{array}{c}\text { Socio-economic } \\
\text { data }\end{array}$ \\
\hline Energy balances & Population \\
\hline Building stock & Urbanisation rate \\
\hline $\begin{array}{c}\text { New } \\
\text { constructions }\end{array}$ & $\begin{array}{c}\text { Electrification } \\
\text { rate }\end{array}$ \\
\hline $\begin{array}{c}\text { Equipment sales } \\
\text { and stock }\end{array}$ & $\begin{array}{c}\text { Gross domestic } \\
\text { product per capita }\end{array}$ \\
\hline $\begin{array}{c}\text { Energy efficiency } \\
\text { indicators }\end{array}$ & $\begin{array}{c}\text { Gross national } \\
\text { income per capita }\end{array}$ \\
\hline
\end{tabular}

Note: ETP stands for Energy Technology Perspectives.

Source: IEA (2020): "Online Annex: Accelerating the transition to sustainable buildings".

\section{Useful energy demand \\ End-use stock accounting}

INPUT

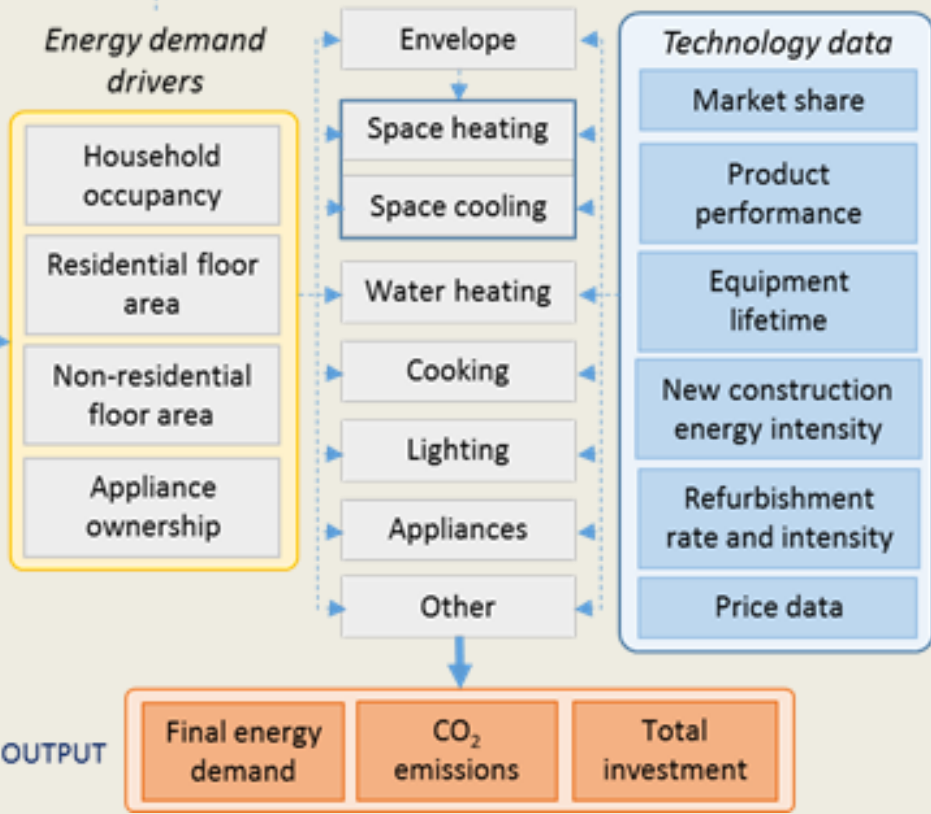




\section{The required deep transformation of housing}

The faster transition scenario projects a clean energy transition in line with internationally agreed objectives on climate change under the Paris Agreement. Energy-related $\mathrm{CO}_{2}$ emissions in this scenario peak around 2020 and then see an annual average decline of $3.6 \%$, dropping to around $10 \mathrm{GtCO}_{2}$ by 2050 (Figure A.8). This requires extremely rapid changes to the global energy system, representing an energy transition of exceptional scope, speed and depth, which leads to an energy sector that is fundamentally different from the new policy scenario that only reflects current and announced policies. Under the FTS, emissions from residential buildings in the OECD decrease by more than $85 \%$, from around $2.2 \mathrm{GtCO}_{2}$ in 2017 to $0.26 \mathrm{GtCO}_{2}$ in 2050 (Figure A.8).

\section{Figure A.8. High ambition is required to bring housing-related emissions down}

$\mathrm{CO} 2$ emissions from residential buildings in the Fast Transition Scenario compared with the New Policies Scenario, 2017-2050

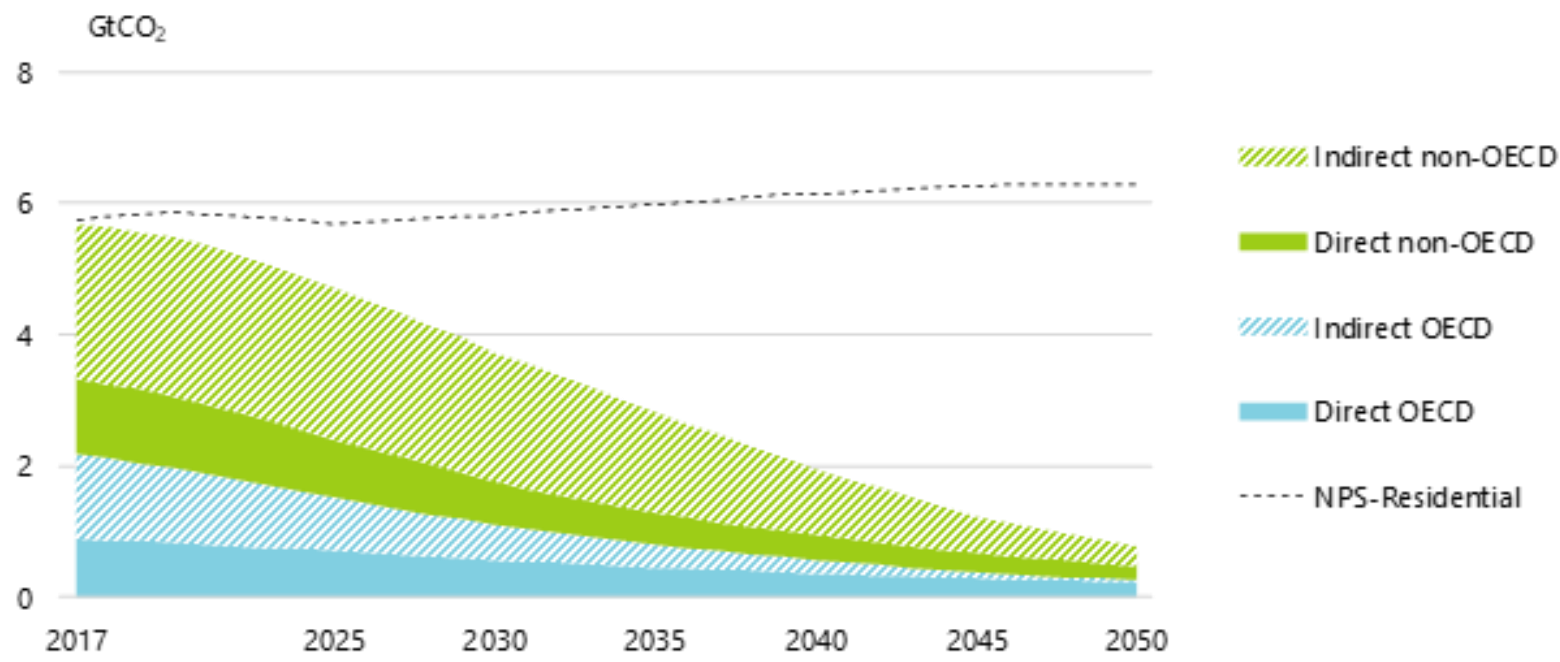

Note: Direct emissions represent $\mathrm{CO}_{2}$ emissions from the use of fossil fuels (coal, oil and natural gas) in buildings. Indirect emissions account for the carbon footprint of the electricity and heat consumed by households.

Source: IEA (2019a), Perspectives for the Clean Energy Transition. The Critical Role of Buildings, IEA Publications.

The residential buildings sector strategy to move towards carbon neutrality relies on three pillars:

- Sufficiency: Upgrading building envelope performance is necessary to reduce energy service demand for heating, cooling and lighting. While building energy codes should also focus on facilitating the integration of low-carbon energy vectors to the built environment (e.g. PV, heat pumps or electric vehicle chargers), accelerated deep-energy renovation is necessary as half of buildings that will be standing in 2050 are already standing today.

- Efficiency: Research, development and demonstration help improve the performance of available technologies and enlarge their applicability (to a greater number of building types or climate conditions).

- Decarbonisation: Low-carbon energy carriers (e.g. solar thermal, bio-energy electricity) provide an alternative to move rapidly away from the use of fossil fuels in houses with coal, oil or natural gas boilers, furnaces and stoves.

Efficiency measures in residential buildings support the decarbonisation of supply sectors. Thus, despite rapid electrification, electricity demand in the FTS is lower than in the NPS, helping power to decarbonise. 
The uptake of flexible energy devices (e.g. smart meters and thermostats, active controls or responsive heat pumps) complements on-site renewable generation (e.g. rooftop solar thermal, PV or geothermal energy) to facilitate the integration of renewable energy sources.

A reallocation of capital in the next decade is critical for achieving a cost-effective implementation of the long-term sustainable development ambitions in the buildings sector. In the faster transition scenario, investments made before 2030 account for two thirds of the direct emission reductions to 2050 and leads to halving the share of household income spent on energy. However, inaction would increase total buildings costs. For instance, delaying FTS building envelope measures by 10 years would result in 3 years of additional heating and cooling demand over the long lifetime of buildings (IEA, 2017[41])

\section{Potential consequences for housing supply and prices}

With respect to the simulation framework outlined in section 2, these measures imply i) an immediate increase in construction costs and ii) an acceleration of the rate at which the existing housing stock is upgraded. The increase in construction costs is assumed to be 10 percentage points. The renewal or upgrade of the existing stock is modelled through a gradual increase in the renovation rate. The renovation rate is assumed to rise by 1 percentage point with respect to the baseline (average renovation rate of $2 \%$ per year). After 2035, the heavy renovation rate declines to a level of $1 \%$ per year by 2050 . Figure A.9 illustrates the simulated impact of the higher construction cost and renovation rate. Affordability deteriorates in all countries. The additional number of years of disposable income varies between 0.2 years in Poland or Latvia and more than 1.5 years in Sweden, Australia or New Zealand. Cross-country heterogeneity is driven by the initial level of the renovation rate and the housing supply elasticities.

\section{Figure A.9. Tightening building standards and accelerating renovation are projected to increase prices}
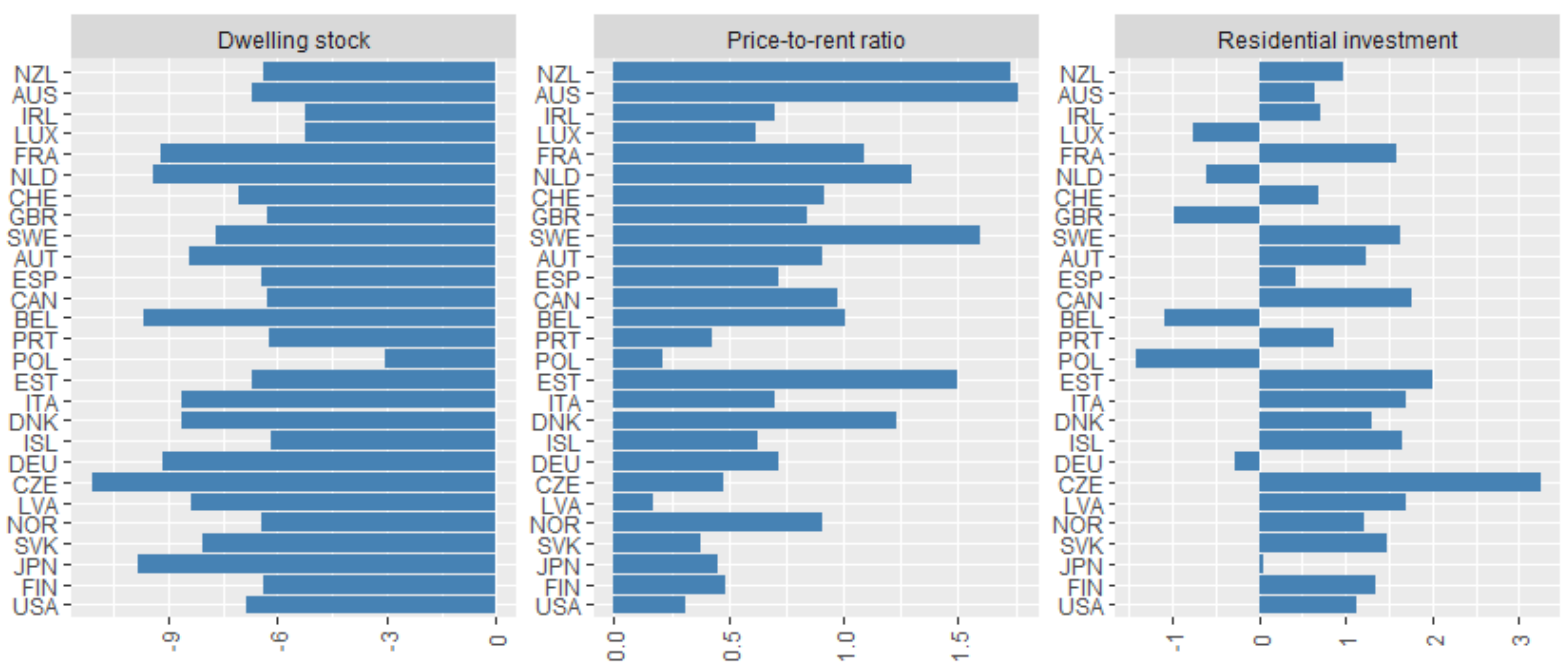

Note: Changes with respect to baseline are shown (percentage points for dwelling stocks and residential investment; number of years of disposable income to purchase a $100 \mathrm{~m}^{2}$ dwelling for price-to-rent ratio). Environmental regulation to move towards carbon neutrality assumes an immediate increase of $10 \%$ in construction costs as well as gradual increase in the heavy renovation rate of one percentage point from baseline heavy renovation rate (varies by country) until 2035. After 2035, the heavy renovation rate declines uniformly towards $1 \%$ per year by 2050 .

Source: OECD calculations. 